\title{
The McDonald Site: An Analysis of WPA Excavations at a Caddo Site in the Glover River Drainage, McCurtain County, Oklahoma
}

Amanda L. Regnier

Oklahoma Archeological Survey

Follow this and additional works at: https://scholarworks.sfasu.edu/ita

Part of the American Material Culture Commons, Archaeological Anthropology Commons, Environmental Studies Commons, Other American Studies Commons, Other Arts and Humanities Commons, Other History of Art, Architecture, and Archaeology Commons, and the United States History Commons

Tell us how this article helped you.

This Article is brought to you for free and open access by the Center for Regional Heritage Research at SFA ScholarWorks. It has been accepted for inclusion in Index of Texas Archaeology: Open Access Gray Literature from the Lone Star State by an authorized editor of SFA ScholarWorks. For more information, please contact cdsscholarworks@sfasu.edu. 
The McDonald Site: An Analysis of WPA Excavations at a Caddo Site in the Glover River Drainage, McCurtain County, Oklahoma

\section{Creative Commons License}

\section{(c) (1) \&}

This work is licensed under a Creative Commons Attribution-NonCommercial 4.0 International License 


\section{THE MCDONALD SITE: An Analysis of WPA ExCAVATIONS AT A CADdo Site in THE Glover River Drainage, McCurtain County, OKLAHOMa}

\section{Amanda L. Regnier}

Between December 1941 and March 1942, the final federally-sponsored WPA excavations in Oklahoma were conducted at the McDonald site, located along the Glover River. Because federal funds for analysis dried up as the country entered into World War II, the recovered artifacts were never fully analyzed. Between 2008-2009, I analyzed the non-mortuary artifacts, which are curated at the Sam Noble Oklahoma Museum of Natural History (SNOMNH) in Norman, and conducted an analysis of recovered stone and ceramic artifacts. Using previously unknown information from a recently unearthed final WPA Quarterly report, in this article I describe excavations and present the results of my analysis. I also incorporate Elsbeth Dowd's (2008, 2010, 2011) previous analysis of the whole vessels recovered from burials into my study and compare the McDonald site material to the assemblages from two downstream mound sites, Clement (Hammerstedt et al. 2010) and A.W. Davis (Wilson 1962).

The analysis identified multiple occupation components at McDonald, including intermittent Late Archaic and Woodland occupations that likely date between 1500 B.C. and AD 600, no evidence of Formative Caddo occupation (AD 900-1100), a possible Sanders phase occupation (AD 1100-1300), and a much larger McCurtain phase (AD 1300-1700) occupation (see Bruseth 1998 for phase descriptions). Based on the whole vessel and sherd assemblage, the site was occupied during the Early (AD 1300-1450), Middle (AD 1450-1650), and Late (AD 1650+) McCurtain sub-phases. The results of this analysis provide a better understanding of Caddo occupation along the Glover drainage. McDonald is approximately 2 miles upstream from the mound sites Clement and A. W. Davis, which have three and one mounds respectively, and is one of a number of sites along the terraces of the lower Glover drainage occupied by the prehistoric Caddo (Figure 1). Ongoing research at Caddo sites along the Glover drainage (see Hammerstedt et al. 2010, Regnier et al. 2013) have determined that the unoccupied mound precinct at Clement was established during the Sanders phase and abandoned during the mid- $15^{\text {th }}$ century, when a new mound was constructed slightly upstream at A.W. Davis. Occupation at McDonald continued through this shift, although there does seem to have been a reduction in the population size in this area of the site by the $17^{\text {th }}$ century. On a larger regional scale, the McDonald ceramic analysis has revealed important differences between ceramic assemblages from contemporaneous sites at the edge of the Ouachita Mountains and along the Red River. Further, Dowd's $(2008,2010,2011,2012)$ comparisons of assemblages from the Mountain Fork and Glover drainages also revealed distinct differences between ceramic styles between Caddo potters in these neighboring drainages. The high degree of stylistic variety across McCurtain phase assemblages and through its long chronological span highlights the need to refine this overly broad phase designation.

\section{The WPA Excavations}

McDonald is located south of a wide bend in the Glover River on a broad alluvial terrace. The Glover, which is the only undammed river in eastern Oklahoma, originates in the Ouachita Mountains and flows south through a piedmont zone where it joins with the Little River. McDonald is just downstream from the point where at which the Glover transitions from the Ouachita Mountains, with narrow alluvial terraces, to the piedmont zone, with much broader terraces. According the to NRCS soil survey, soils in the area are dominated by well-drained fine sandy loams ideal for agricultural use. 


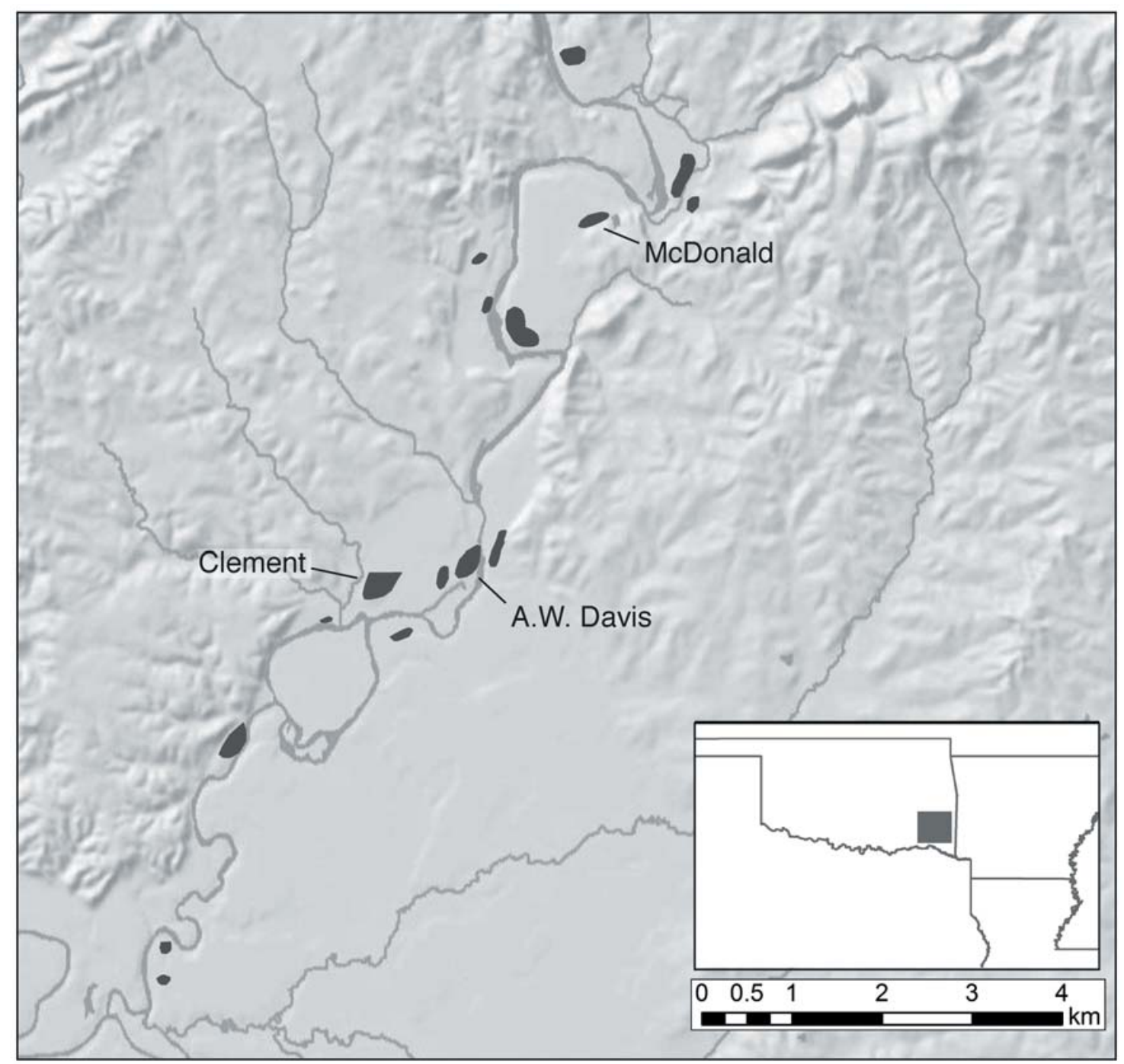

Figure 1. Locations of Caddo sites recorded along the lower Glover River, McCurtain County, Oklahoma.

The WPA excavations at McDonald were conducted by a crew of 17 workers under the supervision of McCurtain County supervisor Jess M. Jones (Figure 2). The project was overseen by David Baerreis, who visited the site periodically, but spent most of his time overseeing the analysis in Norman. The excavations are documented via a variety of sources, none of which have a complete narrative of site excavations. The sources include (a) archaeological data sheets (burial and feature forms), (b) maps of the overall site grid and an excavated circular structure, profile data sheets with elevations, (c) journals from Jones and Baerreis, (d) a published synthesis of Oklahoma archaeology by Bell and Baerreis (1951) and (e) the final quarterly report of excavations authored by Baerreis and submitted to the WPA field office on March 31, 1942. The field notes and journals are on file at the SNOMNH. The existence of a final quarterly report containing Baerreis' summary of the excavations at McDonald came to light in the spring of 2010. While I was looking through a box of David Baerreis' old papers given to the Oklahoma Archaeological Survey, I came upon the carbon copies of several drafts of reports Baerreis prepared for the Clement site excavations of 1941. Among these, I found the final quarterly report, which was not on file either at the SNOMNH or in the University of Oklahoma Libraries Western History Collection, where all of the quarterly reports are housed. This report provided crucial detailed descriptions of the McDonald site not found in any of the previously known notes and forms that have changed our interpretation of the site. The report also contains a preliminary analysis of ceramics from the Clement and McDonald site with tentative pottery type descriptions. 


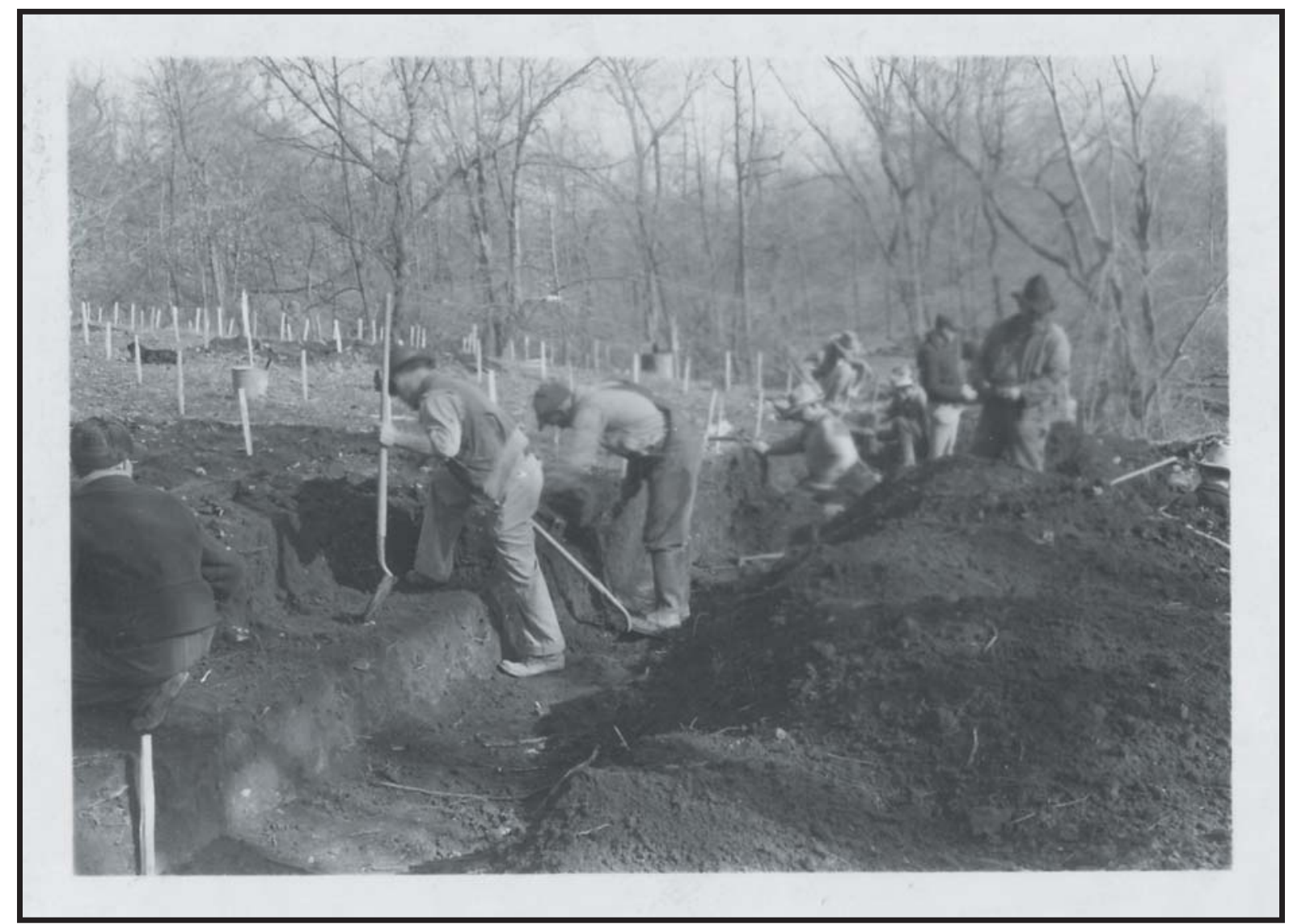

Figure 2. Photograph of WPA crew attributed to the McDonald site. (Photograph used with permission of the Sam Noble Museum).

The first mention of the McDonald site is in Jess Jones' survey notebook, in which he describes visiting a site on land owned by George McDonald on July 21, 1941. Jones describes the area as, "a high sandy field" with cultivated corn and cotton where, "worked stone, pottery, an[d] points" were recovered. At the time, the excavation crew was working on the Clement site. After work was completed at Clement, the excavation crew moved to McDonald, where they began excavations in a midden area designated McMdI (later 34Mc11). The midden is described as two to three feet thick, with abundant sherds and worked stone (Bell and Baerreis 1951:55). Units were excavated in 5-x-5 foot squares given row and column designations and 6-inch levels. The main excavation block measured $100 \mathrm{ft}$ x $100 \mathrm{ft}$. (approximately $30 \times 30 \mathrm{~m}$ ), with an extension on the southwest side measuring $85 \mathrm{ft}$. east-west x $50 \mathrm{ft}$. north-south (approximately 26 x $15 \mathrm{~m}$ ). Thirty burials described as "intrusive into the midden" were excavated in this portion of the site (Baerreis 1942). Of those, 29 were prehistoric Caddo and had very poor bone preservation and one (Burial 11) was identified as historic, based on the better preservation state and traces of a wood coffin and a silver ring. Figure 3 shows the location and orientation of these burials, as well as the chronological affiliation, based on the vessel assemblage.

The second excavated area was designated McMdII (later Mc12), and was approximately 250 west of Mc11. In this area, the grid size was enlarged to measure $10 \times 10$ feet. Prior to the discovery of Baerreis' final quarterly report, the scant excavation notes indicated the only features excavated were a circular structure measuring $18 \mathrm{ft}(5.49 \mathrm{~m})$ in diameter with a northwest facing entryway and two burials located to the south (Figure 4). Frustratingly, few forms were filled out for this portion of the site, and no notes were recorded in Jones' field book after February 6, 1942, although employee time records in the back of the notebook show excavations continued until March 4, 1942. 


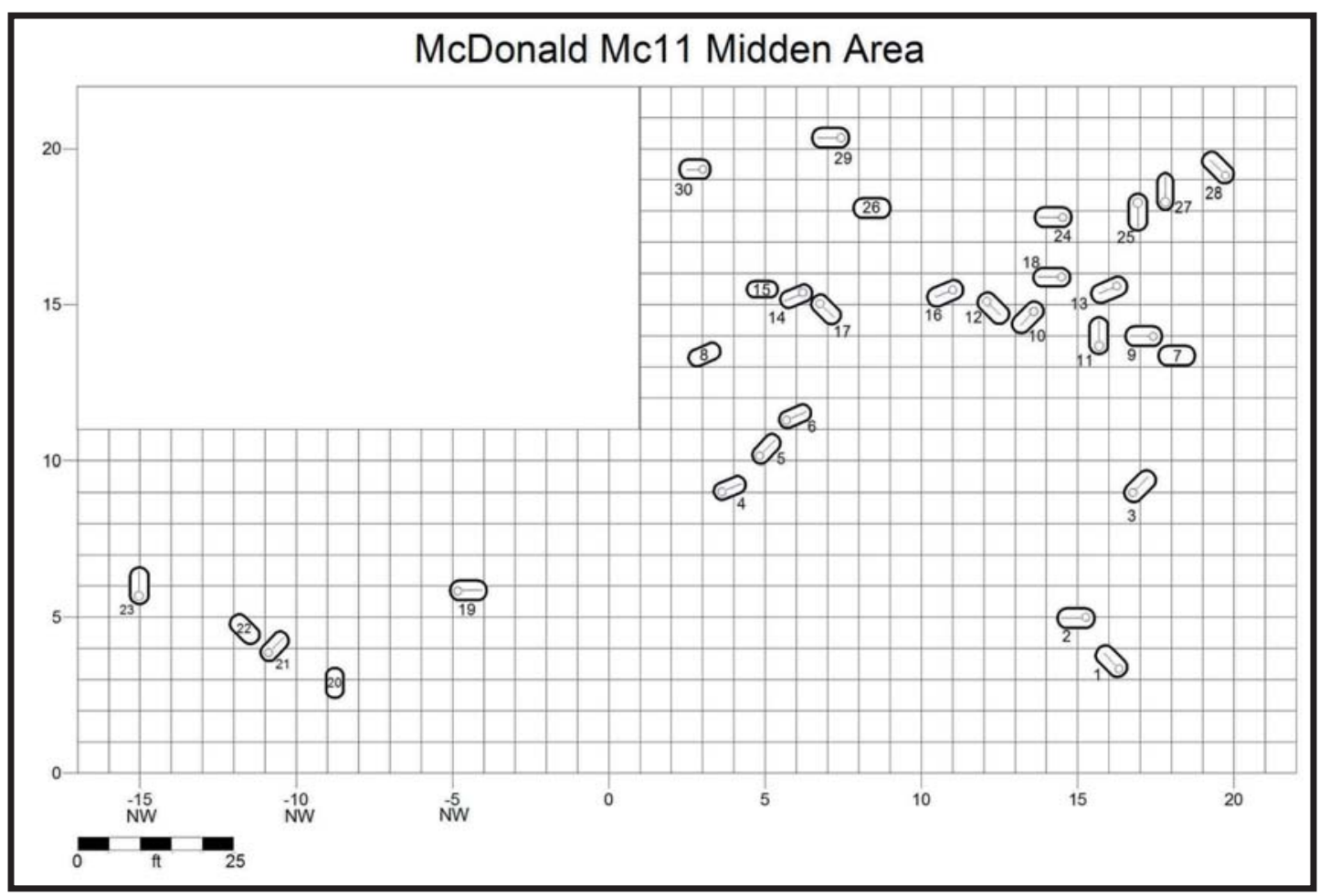

Figure 3. Location of grid units and burials excavated in the Mc11 midden.

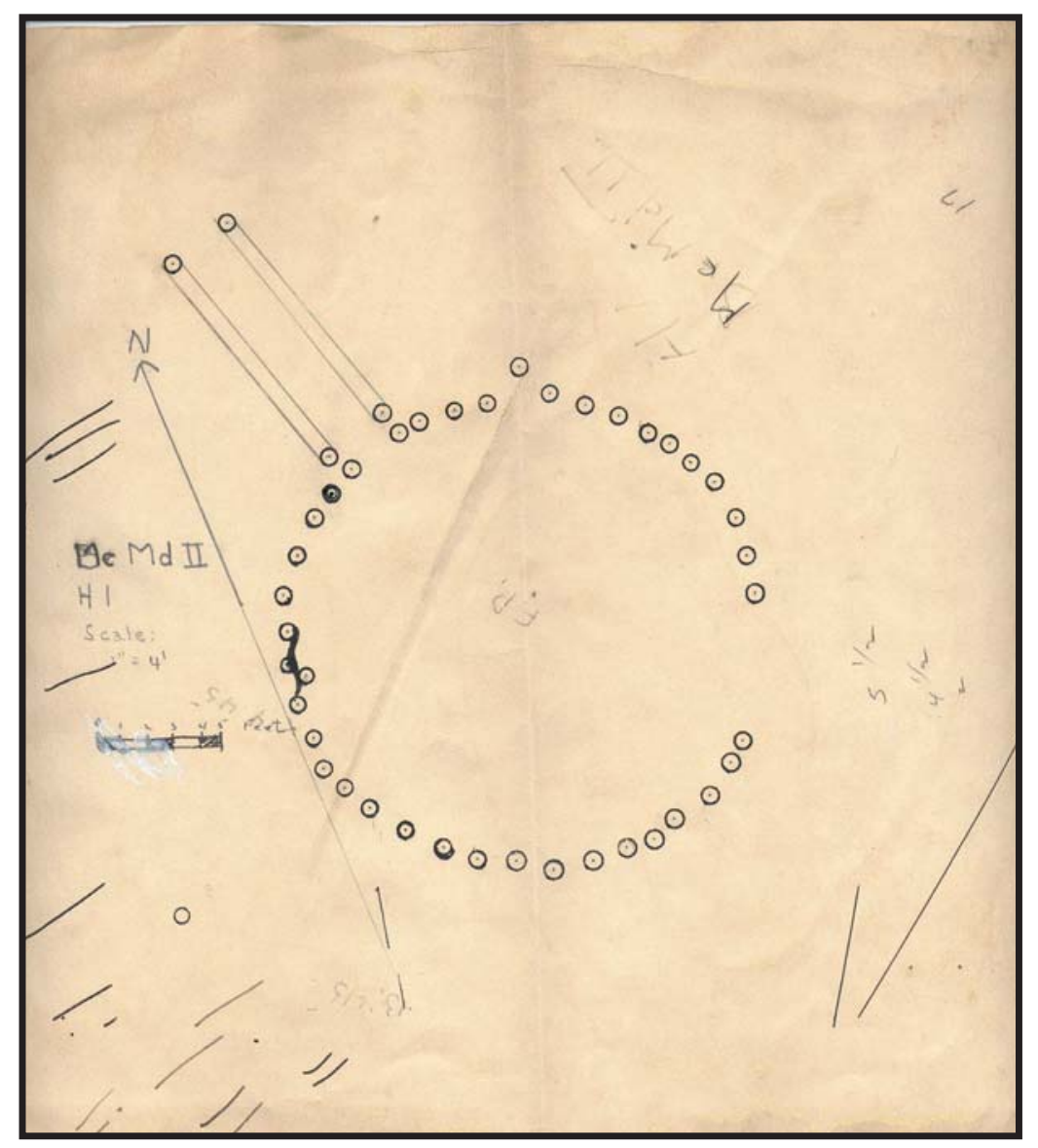

Figure 4. Original map of House 1, the circular structure excavated at Mc12, from WPA notes. (Reproduced with permission of the Sam Noble Museum). 
Baerreis' (1942) quarterly report and his field notebook provide the best description of this portion of the site. In his field notebook, Baerreis sketched the central "fire place" in the circular structure, which consisted of a concentration of burned clay and charcoal flanked by a number of whole and partial vessels, sherds, flat stone slabs, and a mano and metate designated Association 1 (A-1, Figure 5). A large fired clay mass with maize impressions was recovered from the center of the hearth (Figure 6). Given the lack of flotation samples, this artifact at least provides evidence the late Caddo McDonald residents cultivated maize, although it gives no indication how central a role it played in their diets. While one vessel, a vessel base, and a cluster of sherds are depicted on the hearth map, five additional vessels in the collection designated A2-1 through A2-5 are attributed to the floor of House 1 on the original 1942 bags. No forms exist for either A1 and A2 and no coordinates or depths are written on the bags. The presence of all of these artifacts on the floor of House 1 indicates it likely was a domestic structure. Unlike the burned circular structure excavated downstream at Clement (Hammerstedt et al. 2010), McDonald House 1 was not cleaned out before it fell out of use. The artifacts in A1 are all associated with food preparation activities expected to occur around a hearth. All five of the vessels from A2 are relatively small; none are taller than $15 \mathrm{~cm}$ and two are less than $10 \mathrm{~cm}$. The scant field notes unfortunately provide no clue whether the house had burned, and the assemblage represents what was on the house floor, or whether it was unburned and potentially abandoned.

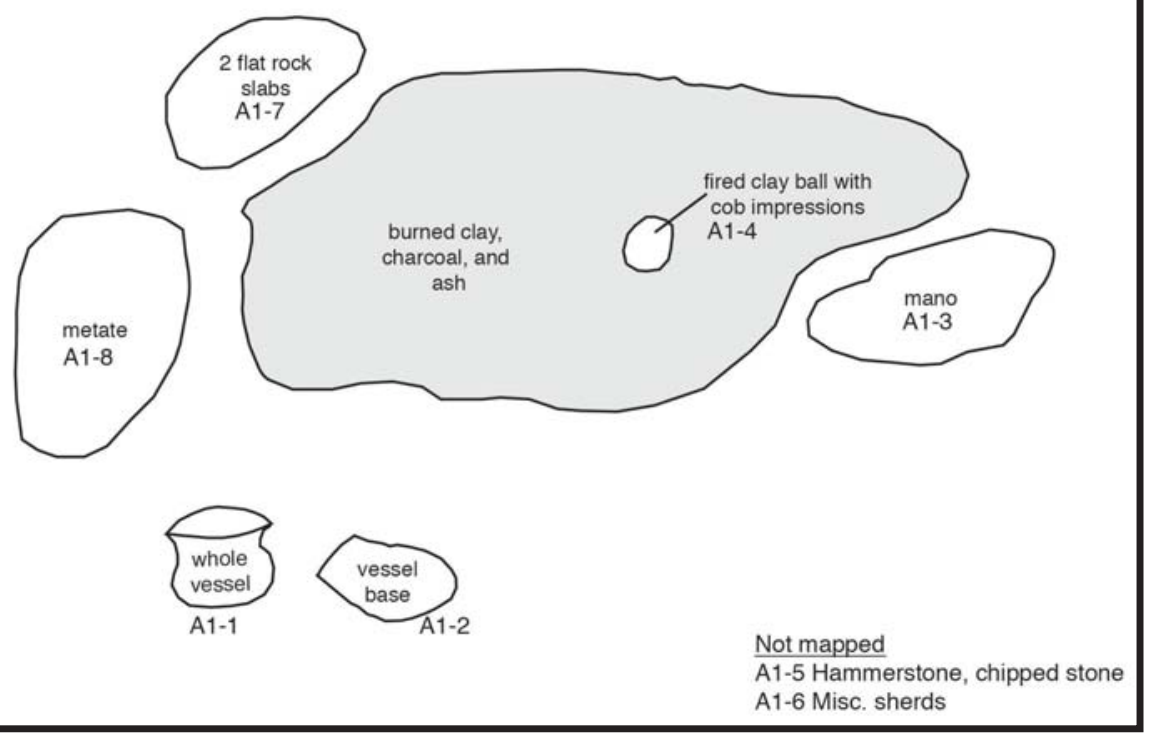

Figure 5. Map of the hearth associations digitized from David Baerreis' field notebook. No scale was included on the original sketch.

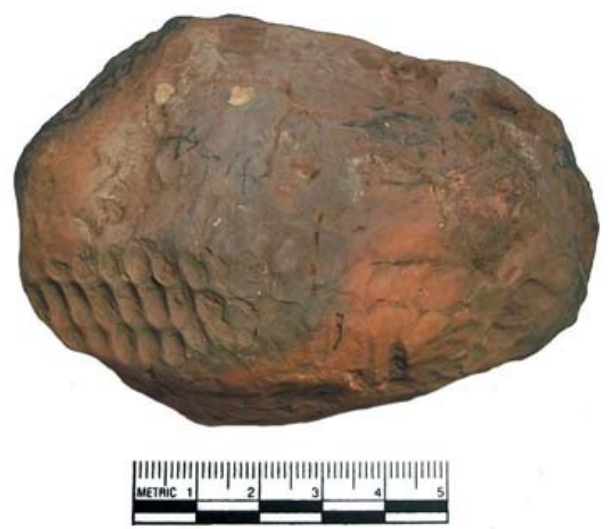

Figure 6. Fired ball of clay with maize impressions (A1-4) recovered from the hearth of House 1 at Mc12. 
In both his field journal and the quarterly report, Baerreis also describes a large "cache pit" near the house. This feature was round and measured 86 " (2.18 $\mathrm{m}$ ) in diameter at the surface. The straight-sided walls tapered down 60 " (1.52 m) to a flat bottom measuring 49" in diameter $(1.24 \mathrm{~m})$. The base of this pit included a whole vessel and three unworked fragments of quartz, most likely quartz crystals. The two burials excavated at Mc12 were shallower than the cache pit, with depths of 48" $(1.21 \mathrm{~m})$ and 45" (1.14 $\mathrm{m})$. It is possible this feature was a burial with extremely poor bone preservation, which Baerreis acknowledges in his field notebook.

In addition to House 1, cache pit, and burials, Baerreis' (1942) quarterly report states that testing in the same field uncovered portions of both round and rectangular houses. None were excavated, since war efforts brought the WPA programs to a close in 1942. These houses are part of what Baerreis (1942) described as, "a sparse mantle of refuse [that] appears to cover the edge of the same terrace upon which unit I was located, for a least a mile up the river." Finding this information in the missing quarterly report answered the lingering question of why a cemetery and midden were present at a site where only one house was known. Based on Baerreis' description, rather than a small farmstead, McDonald appears to be a wide low-density scatter of household clusters, similar to the Hill Farm site on the Texas side of the Great Bend of the Red River documented historically on the 1691-1692 map from the Teran de los Rios expedition and archaeologically by Perttula et al. (2008).

\section{Non-burial Artifacts from the WPA Excavations at Mc11/12}

This artifact analysis describes the artifacts recovered from non-burial contexts. These include the midden at Mc11, the floor of House 1 at Mc12, and several "associations" at both sites, which are most likely burial pits in which no bone was evident. In addition, the 80 vessels or portions of vessels still available for study from burial contexts were assigned type designations and chronological affiliations. When possible, descriptions from WPA burial forms are provided for vessels missing from the collections. Photographs and more extensive documentation of these vessels have already been published by Dowd $(2008,2010,2011)$. Because the soil was not screened and the recovered assemblage is made up of artifacts spotted by WPA excavators, there is a bias toward large sherds and lithic artifacts. Almost no lithic debitage and few of the small arrow points used by the Caddo are present in the artifact assemblage. Despite the lack of screening, the analysis includes an assemblage of 3,558 pottery sherds, 502 of which are decorated, 5 clay pipe fragments, the single fired clay object with maize impressions, 211 lithic artifacts, and 140 faunal specimens. The faunal remains, analyzed by Sheila Bobalik Savage, are primarily unidentified mammal bones. The few identifiable species are from large domesticated animals, including cow and pig. Possible specimens associated with the Caddo occupation include 2 identifiable elements from white-tailed deer and a single element from a black bear. The collection also includes a handful of early $19^{\text {th }}$ century historic transfer-printed and shell-edge decorated ceramics. The historic ceramics and burial and the domestic fauna are likely associated with post-Removal Choctaw inhabitants of the Glover drainage.

\section{Ceramic Vessels}

The assemblage from burials at 34Mc11 and 34Mc12 includes 100 whole and partial vessels. The 80 vessels still available for study have been analyzed by and are pictured in several works by Dowd $(2008,2010$, 2011), where they are used in a broader stylistic study of whole vessels from southeast Oklahoma Caddo sites. The vessel assemblage includes 38 jars, 39 bowls, 13 bottles, and 10 vessels whose forms were not listed in the WPA notes. Table 1 lists basic information about each of these vessels, including tentative type identification, along with any available information from WPA notes about the missing vessels. When possible, each burial assemblage was also assigned a chronological affiliation. Twelve whole or partial vessels were recovered from non-burial contexts, and were analyzed as part of the current study. Two were from 34Mc11 and nine were from 34Mc12. 


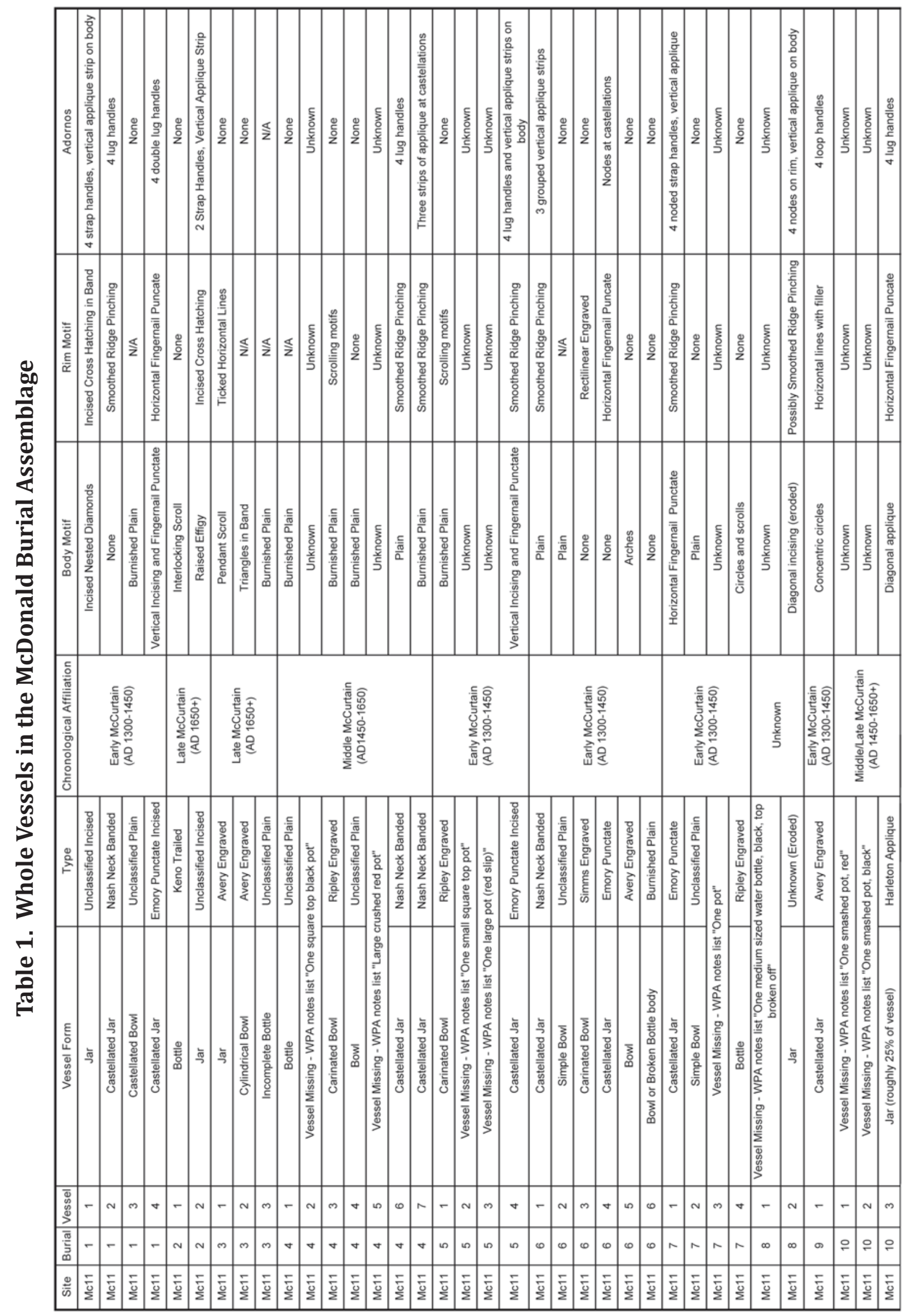




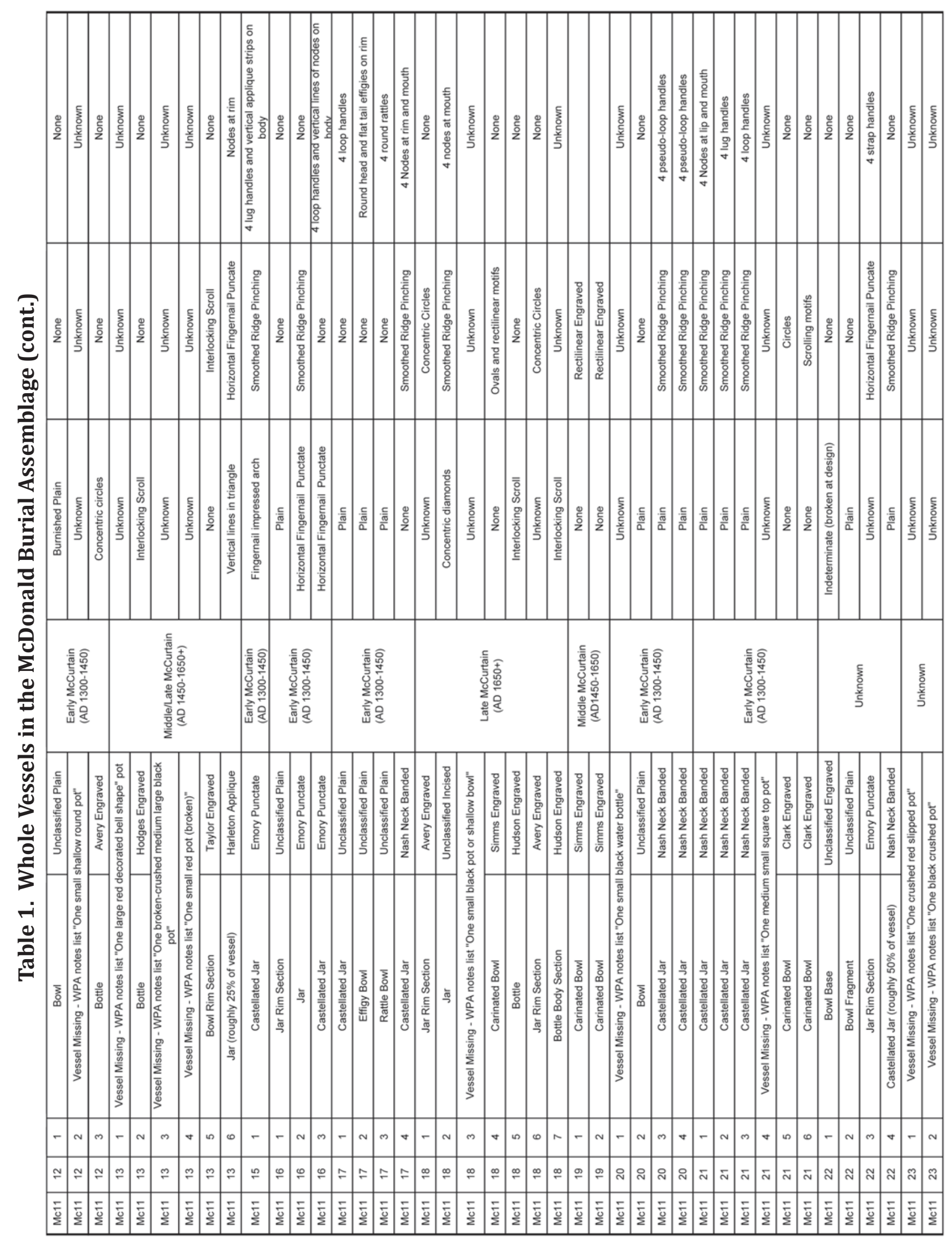




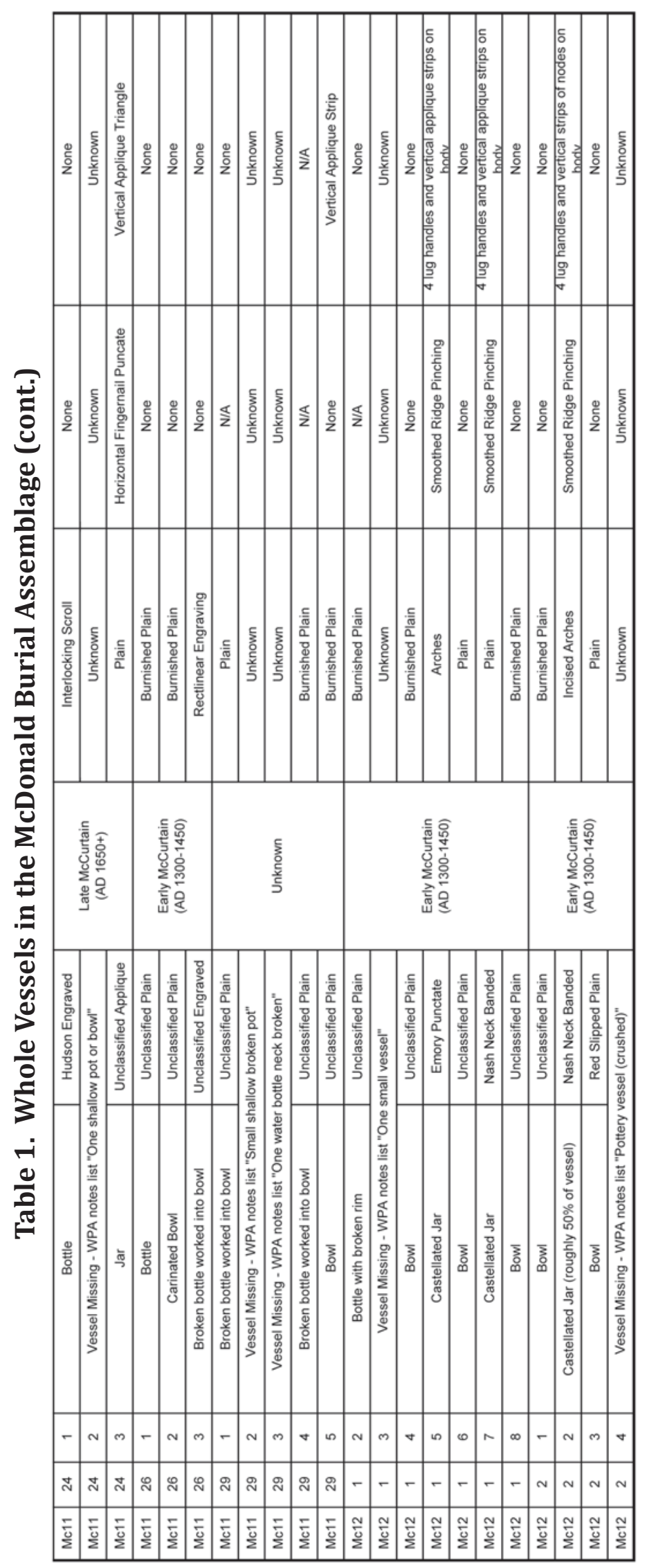

Caddo Archeology Journal • 35 
Vessel A2-1, Cat. 34Mc11/159, Stake 9:1 N 11", E 7", Depth: 27", Level 3

Form: Vessel A2-1 is a jar with portions of rim and one side missing. The exterior surface has a few spalls (Figure 7a). Vessel has a slightly elongated, globular body with an excurvate, everted rim. The lip is rounded. Vessel height is $11.8 \mathrm{~cm}$. Rim height is $2.7 \mathrm{~cm}$ and body height is $9.1 \mathrm{~cm}$ (3.3:1 body to rim ratio). The maximum diameter at the lip is $12.6 \mathrm{~cm}$. The diameter at the shoulder is $11.0 \mathrm{~cm}$.

Temper: Limestone

Type: Emory Punctate

Temporal Affiliation: Early McCurtain phase

Rim Decoration: Vertical lines of fingernail punctations and four vertical applique strips

Body Decoration: Vertical lines of fingernail punctations bounded by a single horizontal band of fingernail punctations and four vertical applique strips

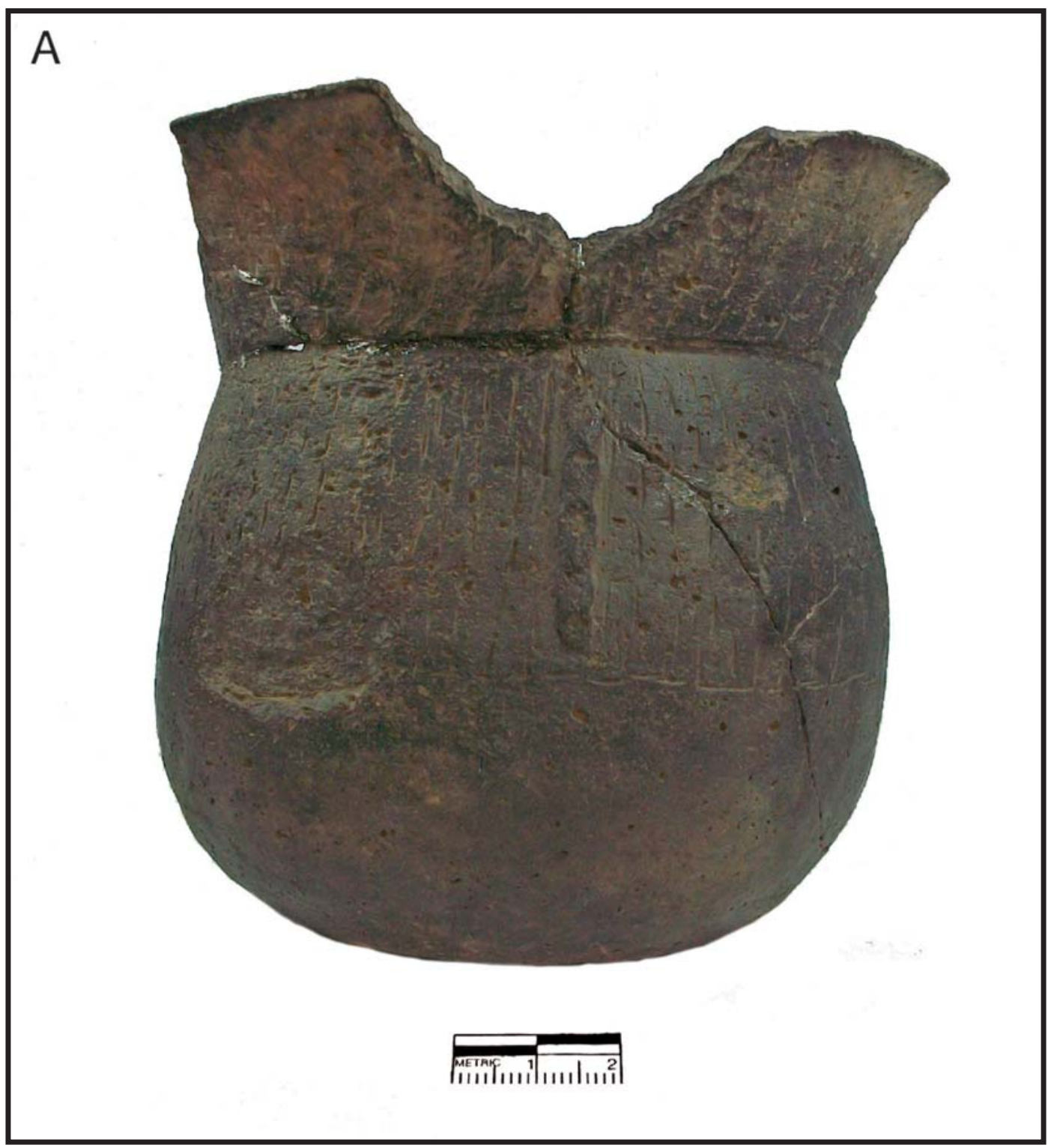

Figure 7a. Whole vessel recovered from Mc11. (Vessel A2-1) 
Vessel A3, Cat. 34Mc11/311, Stake 14:16, N 10", E 4", Depth 26", Level 3

Form: Vessel A-3 is a complete castellated jar. The WPA data sheet states, "this pot was found approx. 14" under burial 9 and might have been the burial of a child but no trace of bones were found." The vessel has a large fire cloud on the shoulder (Figure 7b). Vessel has a globular body with an excurvate, everted rim. The lip is rounded. Vessel height is $11.0 \mathrm{~cm}$. Rim height is $2.8 \mathrm{~cm}$ and body height is $8.2 \mathrm{~cm}$ (2.9:1 body to rim ratio). The maximum diameter, at both the lip and shoulder, is $12.4 \mathrm{~cm}$.

Temper: Shell

Type: Emory Punctate

Temporal Affiliation: Middle McCurtain phase

Rim Decoration: Smoothed ridge pinching with four loop handles just below rim castellations

Body Decoration: Vertical lines of fingernail punctations bounded by a single horizontal band of fingernail punctations. Four vertical lines of five nodes below handles.

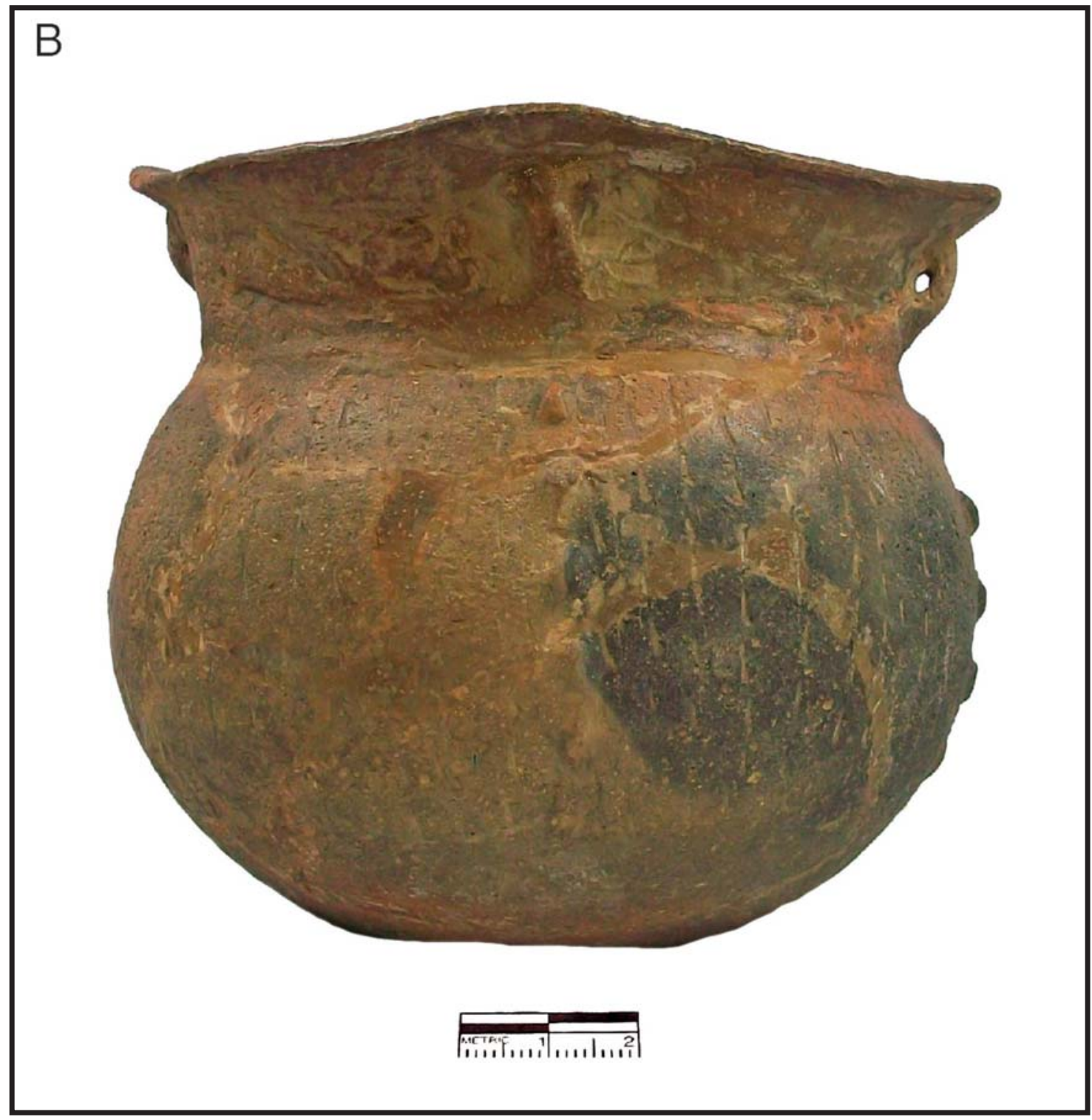

Figure 7b. Whole vessel recovered from Mc11. (B - Vessel A3) 


\section{Vessels from Mc12}

Vessel A1-2, Cat. 34Mc12/18, House 1, South of Hearth, Depth: Not provided

Form: Vessel A1-2 is a castellated jar missing about $1 / 3$ of its rim and body. On Baerreis' sketch map of the fire pit, it was located just south of the hearth next to a complete pot, near flat stones and a mano and metate. The vessel has a globular body with an everted, excurvate rim with a rounded lip (Figure 8a). The vessel is $12.1 \mathrm{~cm}$ tall, with a rim height of $3.2 \mathrm{~cm}$ and a body height of $8.9 \mathrm{~cm}$ (2.8:1 body to rim ratio). The maximum diameter of the vessel is $12.0 \mathrm{~cm}$ at the lip and $10.9 \mathrm{~cm}$ at the shoulder.

Temper: Grog

Type: Nash Neck Banded

Temporal Affiliation: Early McCurtain phase

Rim Decoration: Smoothed ridge pinching. Vertical applique strips at castellations.

Body Decoration: None

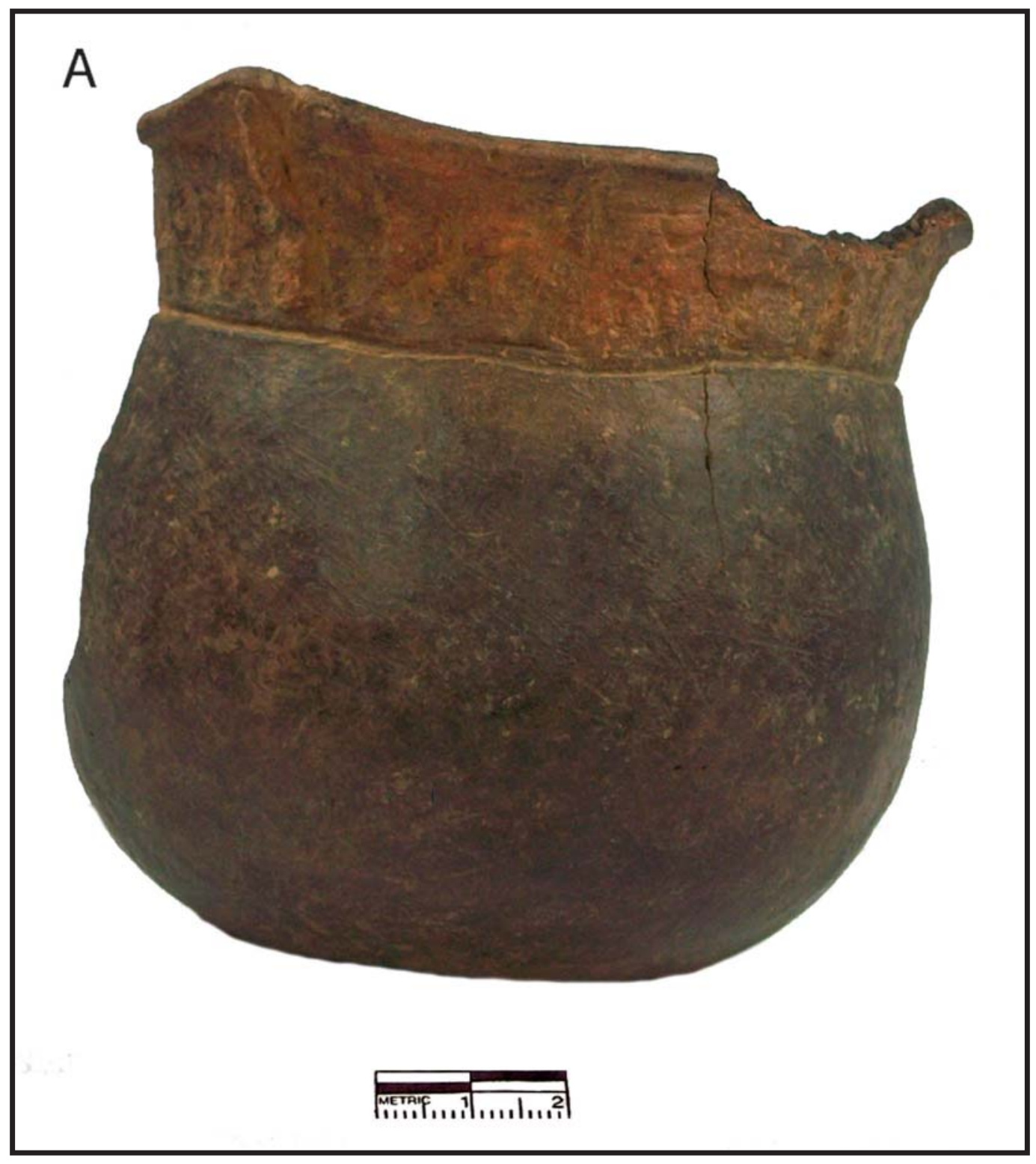

Figure 8a. Whole vessel recovered from floor of House 1 at Mc12. (A- Vessel A1-2) 
Vessel A2-1, Cat. 34Mc12/11, House 1, Depth: Not provided

Form: Vessel A2-1 is a jar missing most of its rim and about a third of its body. The vessel, which has clearly been reconstructed, has an elongated, slightly globular body with an excurvate, everted rim (Figure 8b). The vessel surface is heavily eroded, making it difficult to distinguish any decoration. The lip is missing, making the actual vessel height unknown. The remaining portion of the vessel measures $12.2 \mathrm{~cm}$ tall, and the body height is $8.9 \mathrm{~cm}$. The estimated maximum diameter of the vessel is $12.0 \mathrm{~cm}$ at the lip and $11 \mathrm{~cm}$ at the shoulder.

Temper: Shell

Type: Indeterminate

Temporal Affiliation: Early McCurtain phase

Rim Decoration: Indeterminate

Body Decoration: Indeterminate, except for a vertical line of three nodes likely present at four points on the vessel body.

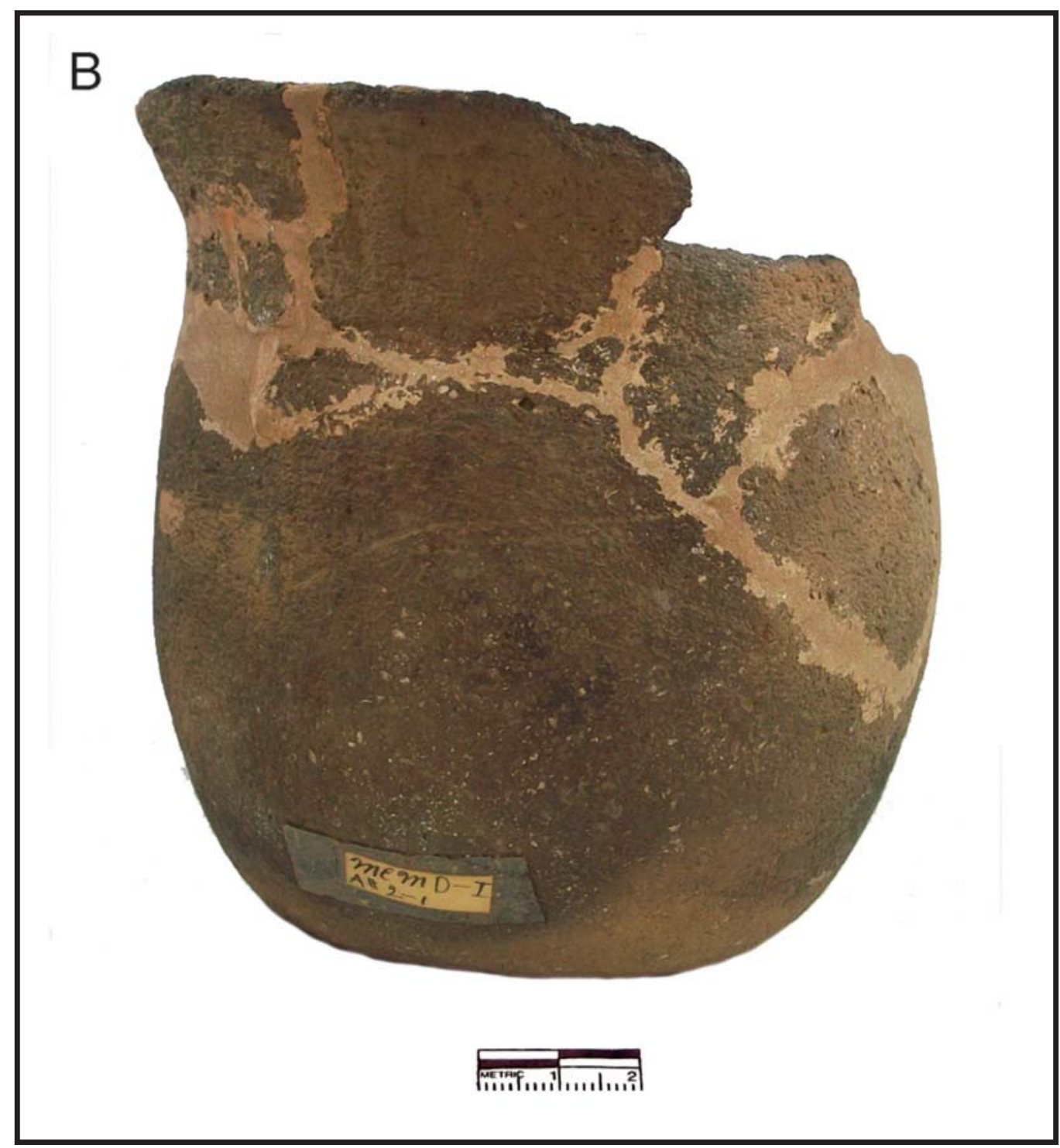

Figure 8b. Partial vessels recovered from floor of House 1 at Mc12. (B - Vessel A2-1) 
Form: Vessel A2-2 is a miniature tall-rimmed, castellated jar. The vessel has a squat, globular body with a straight, everted rim (Figure 8c). The pot is burnished and was clearly fired in an oxygen-reduced environment. The vessel height is $7.0 \mathrm{~cm}$, with a rim and body height of $3.5 \mathrm{~cm} \mathrm{(1:1} \mathrm{body} \mathrm{to} \mathrm{rim} \mathrm{ratio).} \mathrm{The} \mathrm{maximum} \mathrm{vessel}$ diameter is $7.5 \mathrm{~cm}$ at the rim and $6.7 \mathrm{~cm}$ at the shoulder.

Temper: Grog

Type: Unspecified Engraved

Temporal affiliation: Early McCurtain phase

Rim Decoration: Paired diagonal lines that do not tie into scrolls on body. Red pigment was rubbed into engraved lines. Four small loop handles at rim castellations.

Body decoration: Concentric circles executed with paired double lines. Red pigment was rubbed into engraved lines.

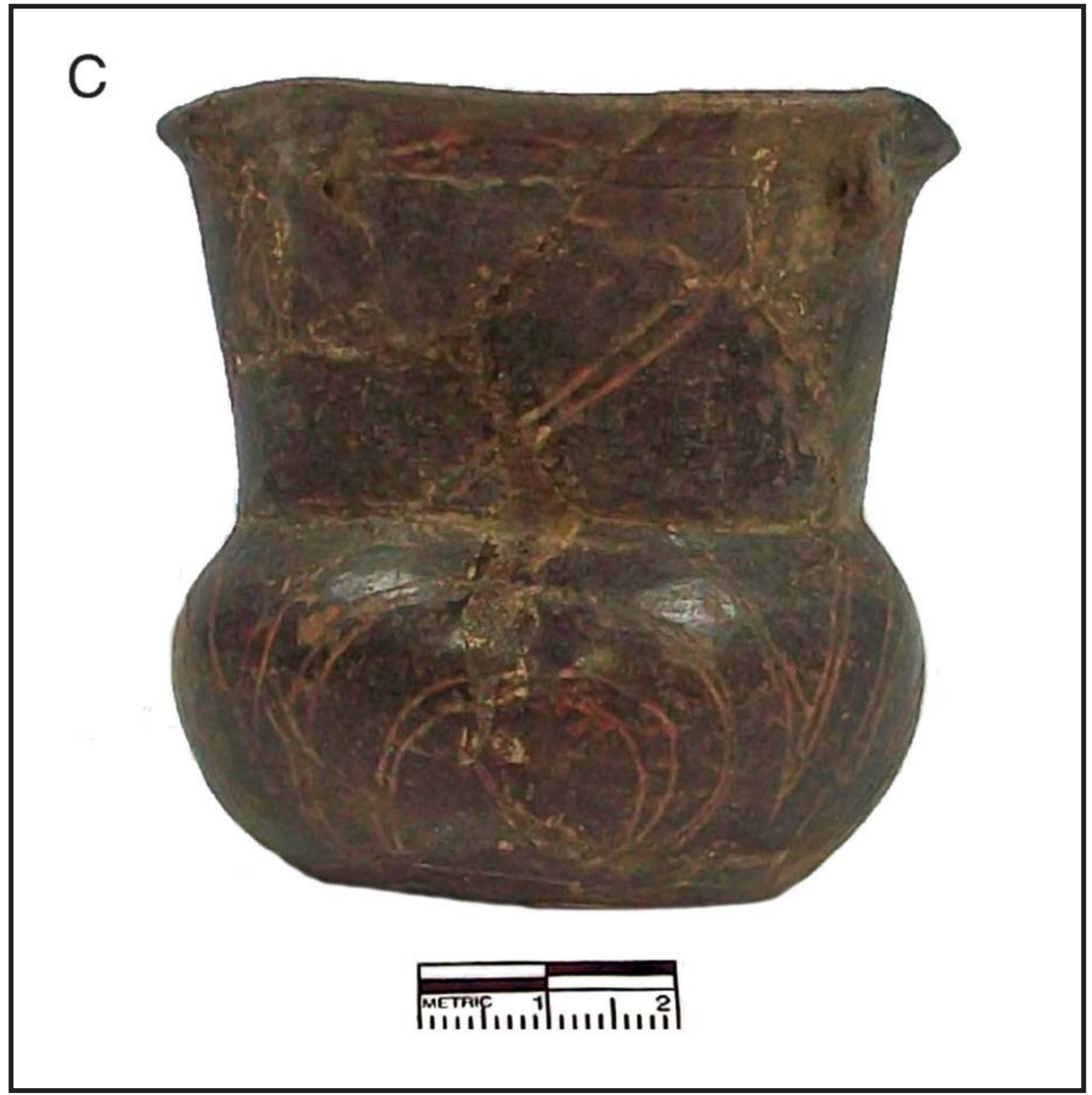

Figure 8c. Whole and partial vessels recovered from floor of House 1 at Mc12. (C - Vessel A2-2) 
Vessel A2-3, Cat. 34Mc12/13, House 1, Depth: Not provided

Form: Vessel A2-3 is a castellated jar approximately $1 / 3$ complete (Figure $8 d$ ). The jar has an oblong body with an excurvate, everted rim and a round lip. Vessel height and diameter are unknown, as the base and most of the rim are missing.

Temper: Grog

Type: Nash Neck Banded

Temporal Affiliation: Early/Middle McCurtain phase

Rim Decoration: Smoothed ridge pinching. Four vertical pinched applique strips below the vessel lip.

Body Decoration: Three horizontal incised lines encircle vessel. Four pinched vertical applique strips below the vessel lip.

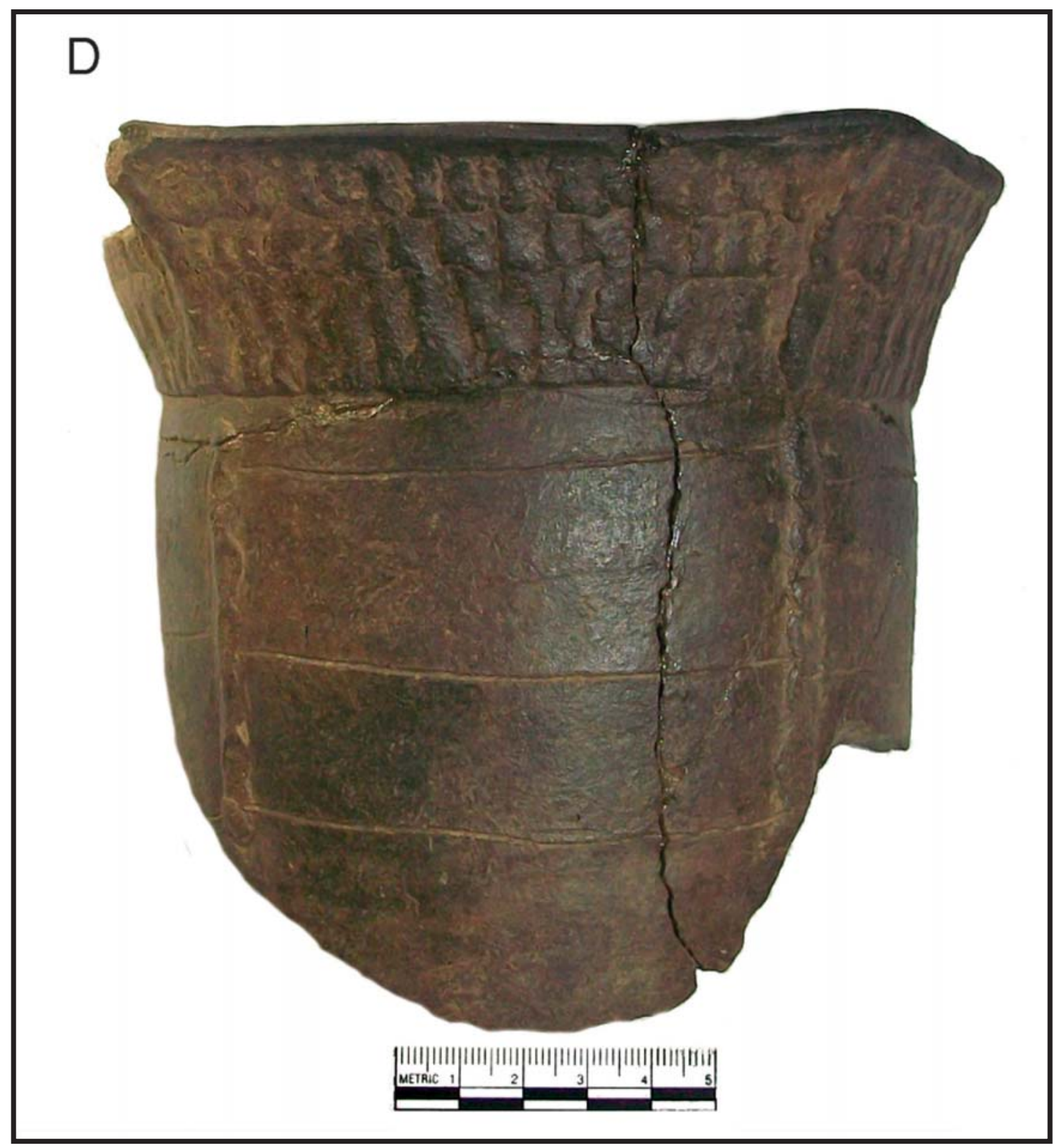

Figure 8d. Partial vesselsrecovered from floor of House 1 at Mc12. (D - Vessel A2-3) 
Vessel A2-4, Cat. 34Mc12/14, House 1, Depth: Not provided

Form: Vessel A2-4 is a castellated jar. The vessel has an oblong body with an excurvate, everted rim and a round lip (Figure 8e). The vessel height is $14.1 \mathrm{~cm}$, with a rim height of $3.4 \mathrm{~cm}$ and a body height of $11.7 \mathrm{~cm}(3.4: 1$ body to rim ratio). The maximum diameter is $12.7 \mathrm{~cm}$ at the rim and $9.5 \mathrm{~cm}$ at the shoulder.

Temper: Grog

Type: Nash Neck Banded

Temporal Affiliation: Early McCurtain phase

Rim Decoration: Smoothed ridge pinching. Four grooved strap handles below the rim castellations.

Body decorations: Three incised horizontal bands. Four vertical applique strips with finger impressions below handles.

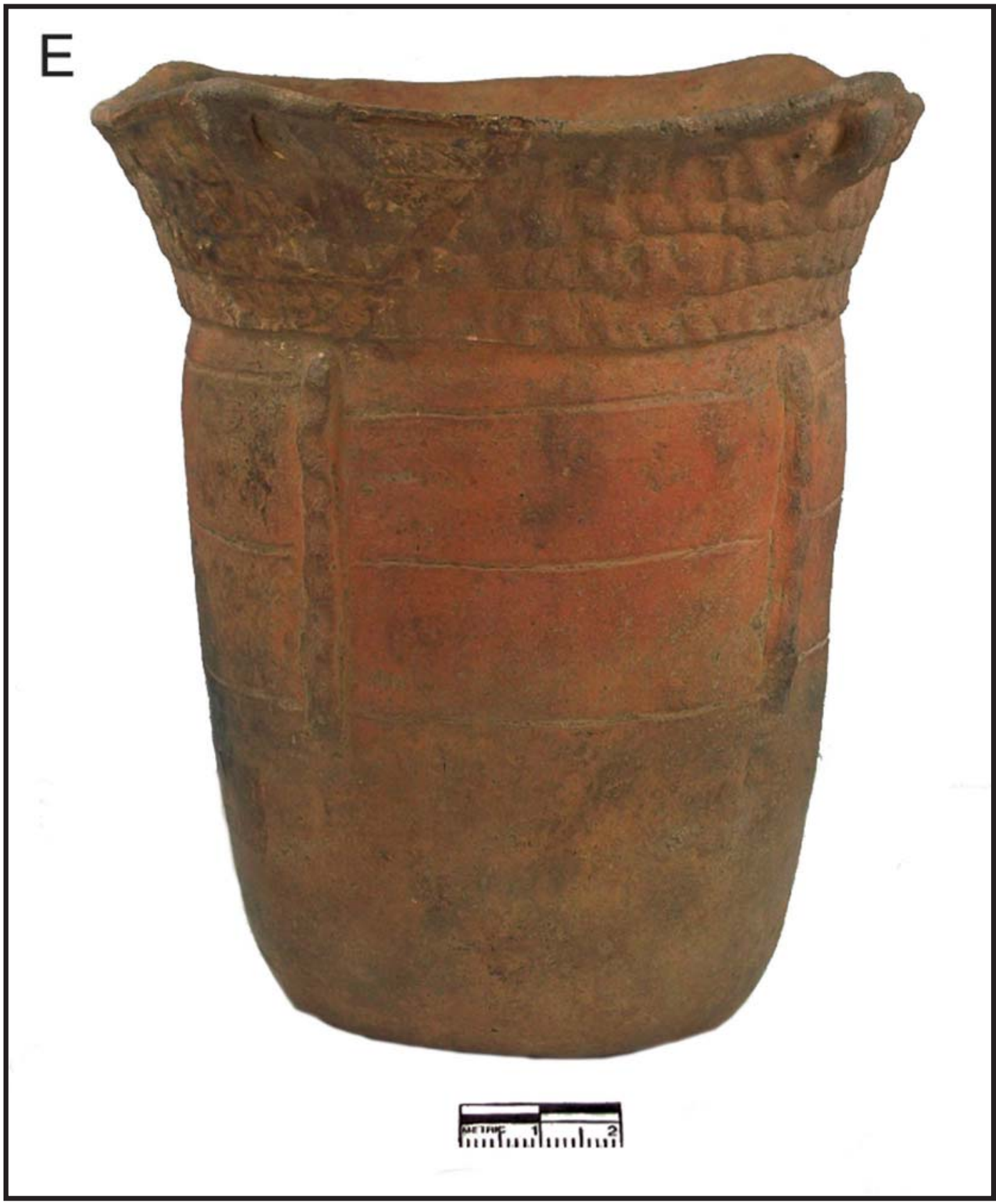

Figure 8e. Whole vessel recovered from floor of House 1 at Mc12. (E - Vessel A2-4) 
Vessel A2-5, Cat. 34Mc12/15, House 1, Depth: Not provided

Form: Vessel A-5 is a miniature bottle with a broken lip (Figure 8f). The vessel has an elongated globular body. The height of the incomplete pot is $9.4 \mathrm{~cm}$. The maximum diameter of the body is $6.7 \mathrm{~cm}$.

Temper: Grog

Type: Unclassified Plain (burnished)

Temporal Affiliation: Unknown

Neck Decoration: None

Body Decoration: None

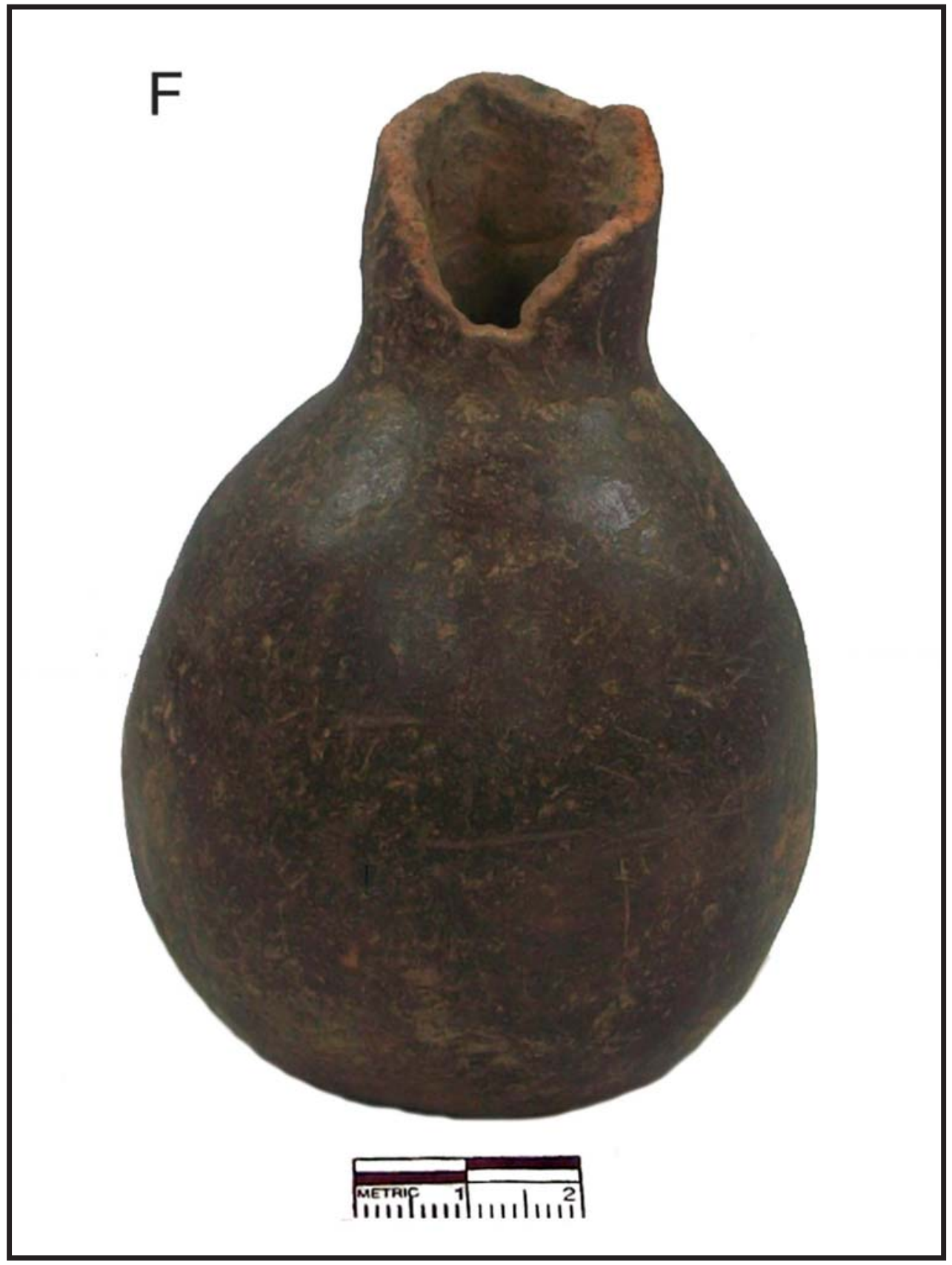

Figure 8.f Partial vessel recovered from floor of House 1 at Mc12. (F - Vessel A2-5) 
Form: Vessel A3-2 is a castellated jar with portions of one side missing. The WPA data sheet indicates that A3 consisted of a grouping of five artifacts, three whole vessels, a group of sherds, and a chipped stone hoe in a fourinch deep area measuring 26" N-S x 18" E-W. No depth was listed for this feature. The vessel has an elongated, slightly globular body with an excurvate, everted rim (Figure 9a). The lip is rounded. The rim castellations are double rather than single peaks. Vessel height is $11.0 \mathrm{~cm}$. Rim height is $2.5 \mathrm{~cm}$ and body height is $8.5 \mathrm{~cm}(3.4: 1$ body to rim ratio). Because the vessel is incomplete, the maximum diameter is unknown, but is estimated to be about $15 \mathrm{~cm}$ at the lip and about $12 \mathrm{~cm}$ at the shoulder.

Temper: Grog

Type: Emory Punctate

Temporal Affiliation: Early McCurtain phase

Rim Decoration: None. Diagonal tick marks are present along the lip exterior and the jar has four loop handles just below the rim castellations.

Body Decoration: Horizontal lines of fingernail impressions and four sets of three vertical applique strips below handles.

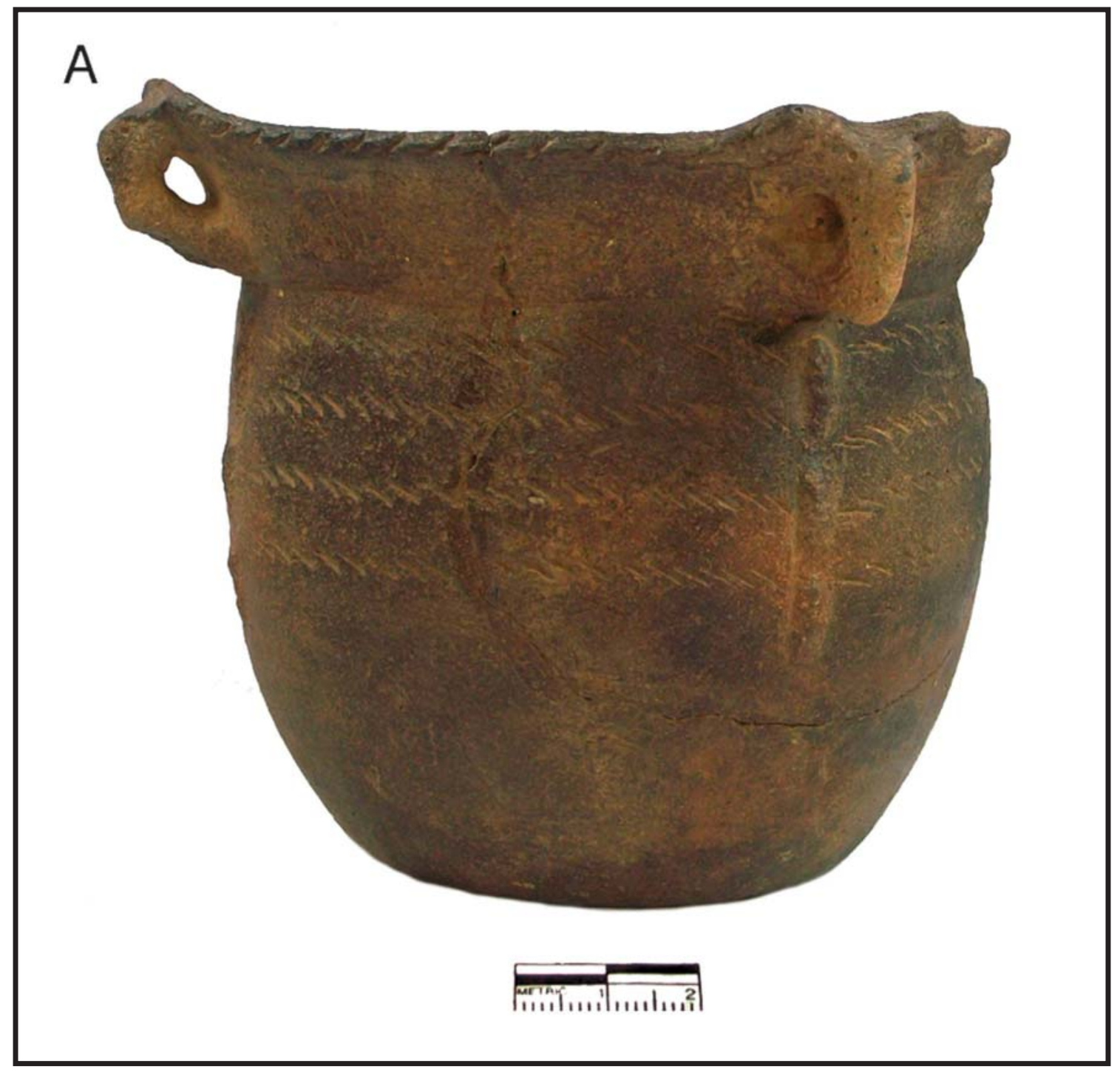

Figure 9a. Whole vessels from Mc12, Association 3. (A - Vessel A3-2, Cat. 34Mc12/6, Stake 4:45) 
Form: Vessel A3-3 is a castellated jar with portions of one side missing. The vessel has a globular body with a straight, everted rim. There is a large fire cloud on the vessel shoulder (Figure 9b). The lip is rounded and the rim castellations are double, rather than single, peaks. Vessel height is $11.2 \mathrm{~cm}$. Rim height is $2.6 \mathrm{~cm}$ and body height is $8.6 \mathrm{~cm}$ (3.3:1 body to rim ratio). Because the vessel is incomplete, the maximum diameters of $15.0 \mathrm{~cm}$ at the lip and $14.0 \mathrm{~cm}$ at the shoulder are estimated.

Temper: Grog with limestone inclusions

Type: Emory Punctate

Temporal Affiliation: Early McCurtain phase

Rim Decoration: Smoothed ridge pinching with four loop handles at castellations

Body Decoration: Perpendicular vertical and horizontal lines of fingernail impressions and four sets of three vertical applique strips below handles

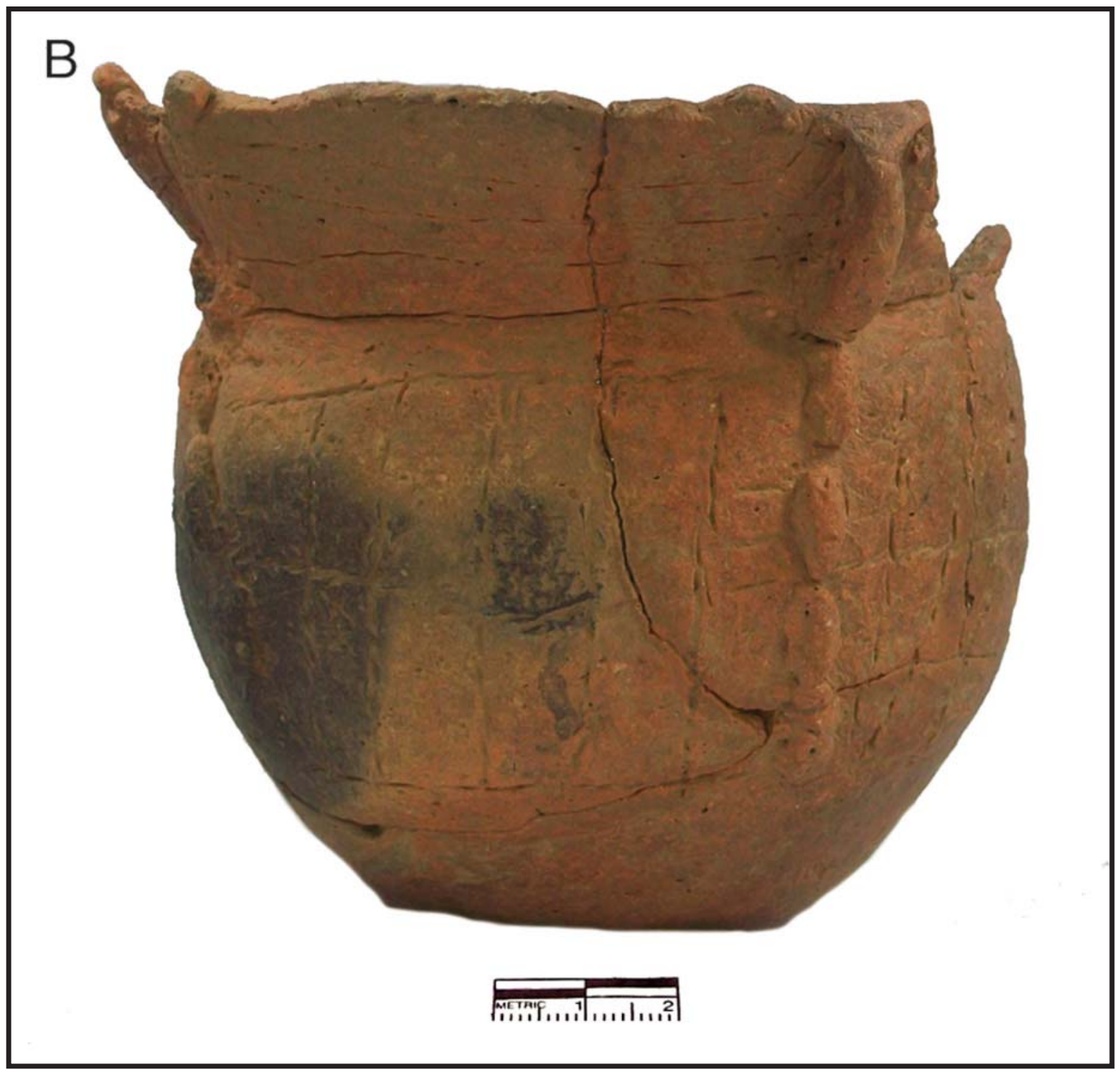

Figure 9b. Whole vessels from Mc12, Association 3. (B - Vessel A3-3, Cat. 34Mc12/7, Stake 4:45) 
Form: Vessel A3-4 is a jar missing most of its rim and about a third of its body. The vessel has a squat globular body with a straight, everted rim (Figure 9c). The vessel surface is moderately eroded. The lip is missing, therefore the actual vessel height is unknown. The remaining portion of the vessel is $9.5 \mathrm{~cm}$ in height, and the body height is $6.3 \mathrm{~cm}$. Maximum diameter is estimated to be $14 \mathrm{~cm}$ at lip and $12.7 \mathrm{~cm}$ at the shoulder.

Temper: Shell

Type: Emory Punctate

Temporal Affiliation: Early/Middle McCurtain phase

Rim Decoration: Horizontal bands of fingernail impressions. Portion of a single broken strap handle is present. Body Decoration: Horizontal bands of fingernail impressions. Vertical lines of three nodes below handles.

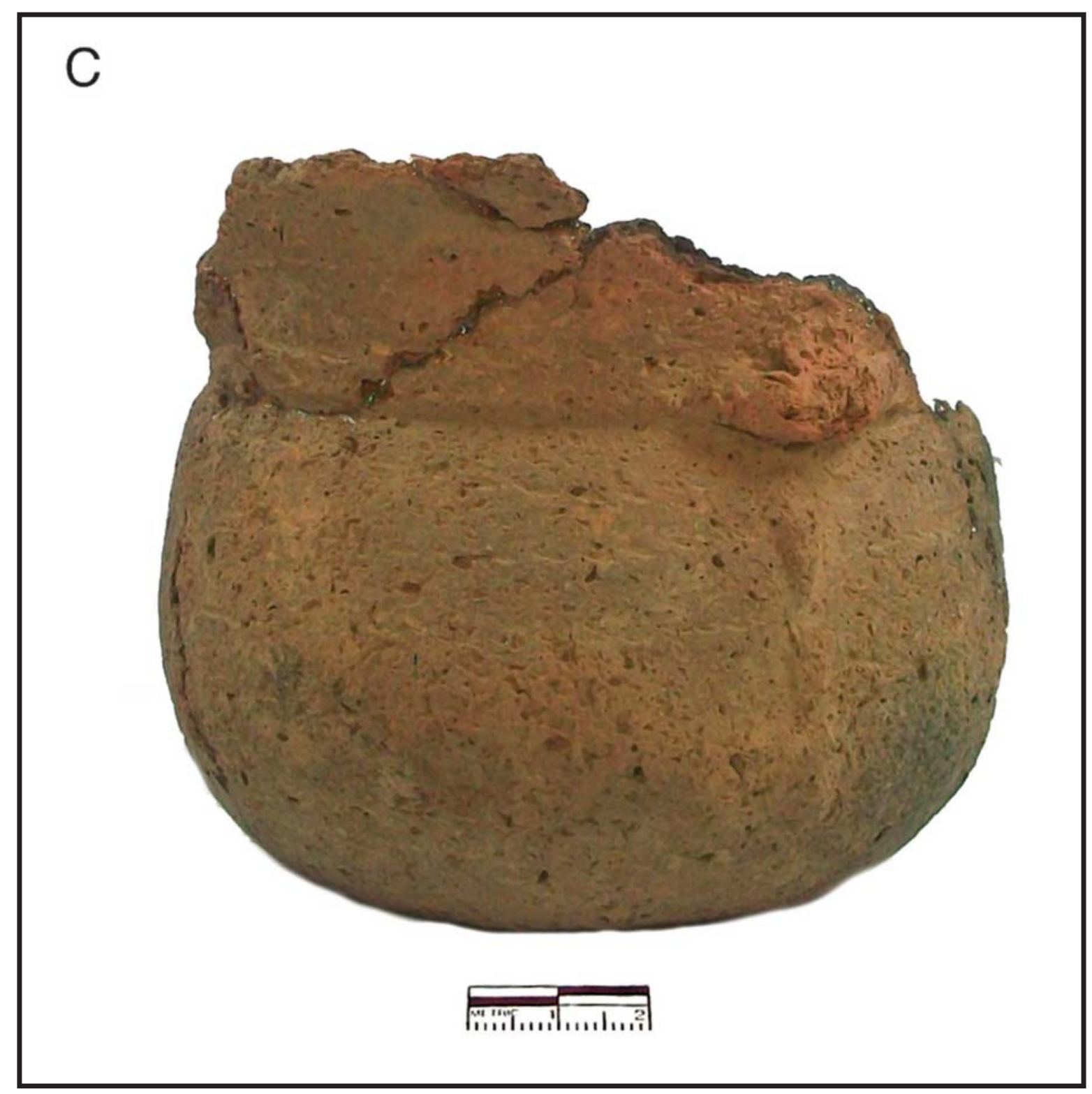

Figure 9c. Partial vessels from Mc12, Association 3. (C - Vessel A3-4, Cat. 34Mc12/8, Stake 4:45) 
Vessel C-1, Cat. 34Mc12/20, Cache Pit 1, Depth: 80"

Form: Vessel C-1 is an incurvate bowl with a rounded lip that appears to have been made from a broken, reworked jar or possibly a bottle (Figure 10). It was excavated from the base of Cache Pit 1 adjacent to four pieces of quartz. The vessel height is $7.3 \mathrm{~cm}$, with a maximum diameter of $14.0 \mathrm{~cm}$.

Temper: Limestone

Type: Unclassified Plain (burnished)

Temporal Affiliation: Unknown

Body decoration: None

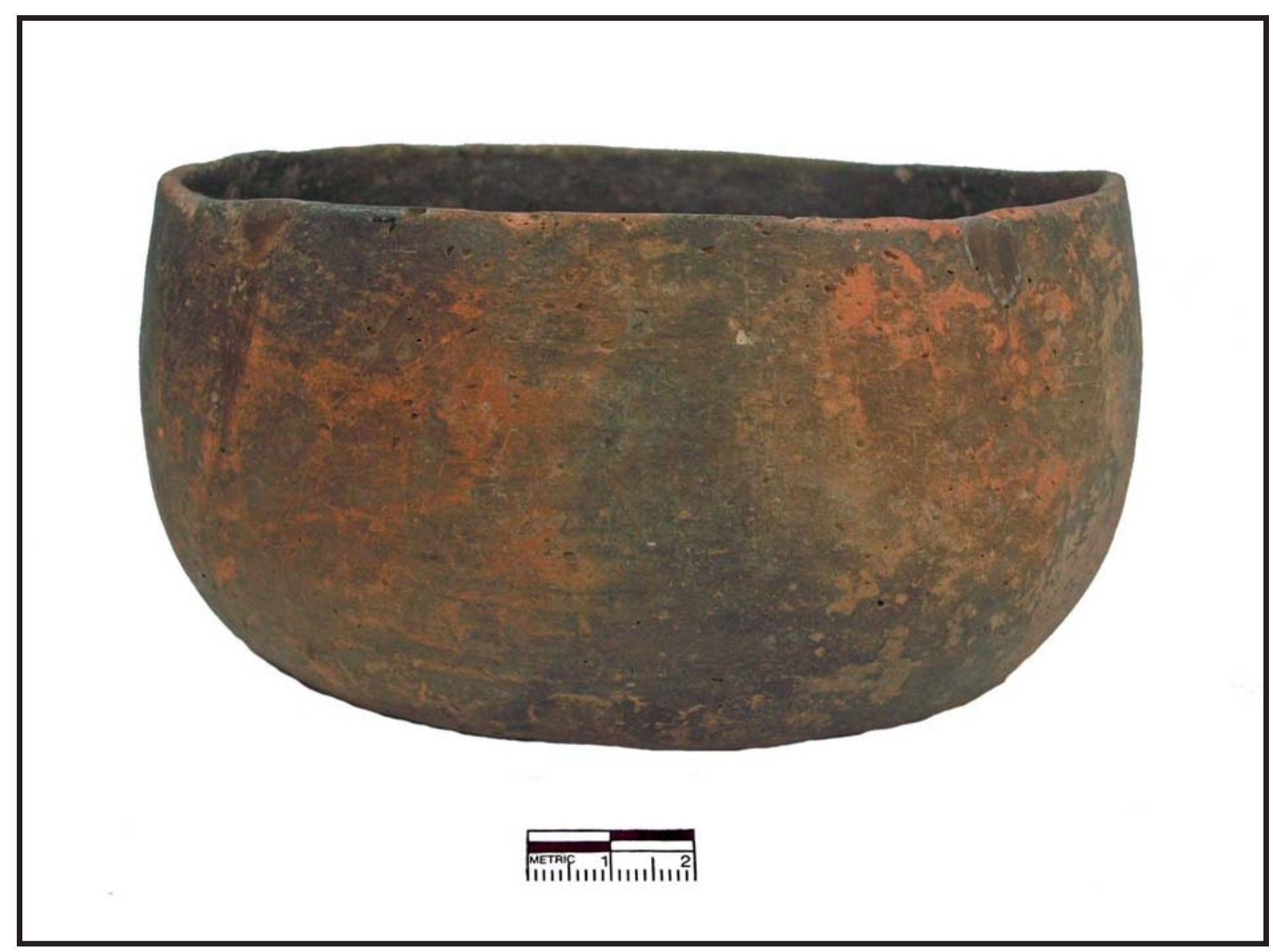

Figure 10. Whole vessel from Mc12, Cache Pit 1 (C1-1) 


\section{Ceramic Sherds}

Of the 3,558 recovered sherds, 3,403 were from Mc11 and 155 were from Mc12. In order to make better sense of the activities occurring in both areas of the site, I will treat both decorated assemblages separately, and further separate the Mc11 sherds into midden $(n=2,878)$ and test pit or surface $(n=555)$ contexts. Table 2 provides the breakdown of decorated and vessel landmark sherds by site context. As seen in Table 3, grog was the dominant tempering agent in assemblages from all three contexts, trailed by shell, dolomitic limestone, and bone. Initially, the dolomitic limestone tempering was confused with bone, because particles were white and rounded. However, when examined under 40x magnification, it was became these were not fragments of bone. The tempering agent reacts very slowly with dilute hydrochloric acid, which is typical of dolomitic limestone, which does occur in the Ouachita Mountains. In addition to the sherds with remaining limestone temper particles, a number of sherds had leeched temper with rounded voids instead of the flat voids typical of shell, which are also assumed to be limestone tempered (Figure 11). Limestone tempering is also seen in the Clement assemblage. Shell-tempered sherds make up $12.2 \%$ of the Mc11 midden assemblage, and only $9.7 \%$ of the total assemblage.

Table 2. McDonald Ceramic Category Counts

\begin{tabular}{|l|c|c|c|c|}
\hline & Mc11 Midden & $\begin{array}{c}\text { Mc11 Test Pits/ } \\
\text { Surface }\end{array}$ & Mc12 & Totals \\
\hline Decorated Sherds & 422 & 134 & 19 & 575 \\
\hline Plain Body Sherds & 1983 & 341 & 112 & 2436 \\
\hline Plain Red-Slipped Sherds & 157 & 35 & 8 & 200 \\
\hline Plain Rim Sherds & 199 & 30 & 13 & 242 \\
\hline Plain Red-Slipped Rims & 18 & 0 & 1 & 19 \\
\hline Plain Base Sherds & 68 & 15 & 2 & 85 \\
\hline Plain Red-Slipped Bases & 1 & 0 & 0 & 1 \\
\hline Total Sherds & 2848 & 555 & 155 & 3558 \\
\hline
\end{tabular}

Table 3. McDonald Ceramic Tempers

\begin{tabular}{|c|c|c|c|c|c|c|c|c|}
\hline \multirow{2}{*}{ Primary Temper } & \multicolumn{2}{|c|}{ Mc11 Midden } & \multicolumn{2}{|c|}{ Mc11 Test Pits/Surface } & \multicolumn{2}{|c|}{ Mc12 } & \multicolumn{2}{|c|}{ Totals } \\
\hline & Count & Percent & Count & Percent & Count & Percent & Count & Percent \\
\hline Grog & 2133 & 82.7 & 541 & 97.5 & 151 & 97.4 & 2825 & 86.0 \\
\hline Limestone & 127 & 4.9 & 1 & 0.2 & 0 & 0.0 & 128 & 3.9 \\
\hline Shell & 313 & 12.2 & 10 & 1.8 & 0 & 0.0 & 323 & 9.7 \\
\hline Bone & 5 & 0.2 & 3 & 0.5 & 4 & 2.6 & 12 & 0.4 \\
\hline Total & 2578 & 100 & 555 & 100 & 155 & 100 & 3288 & 100 \\
\hline
\end{tabular}

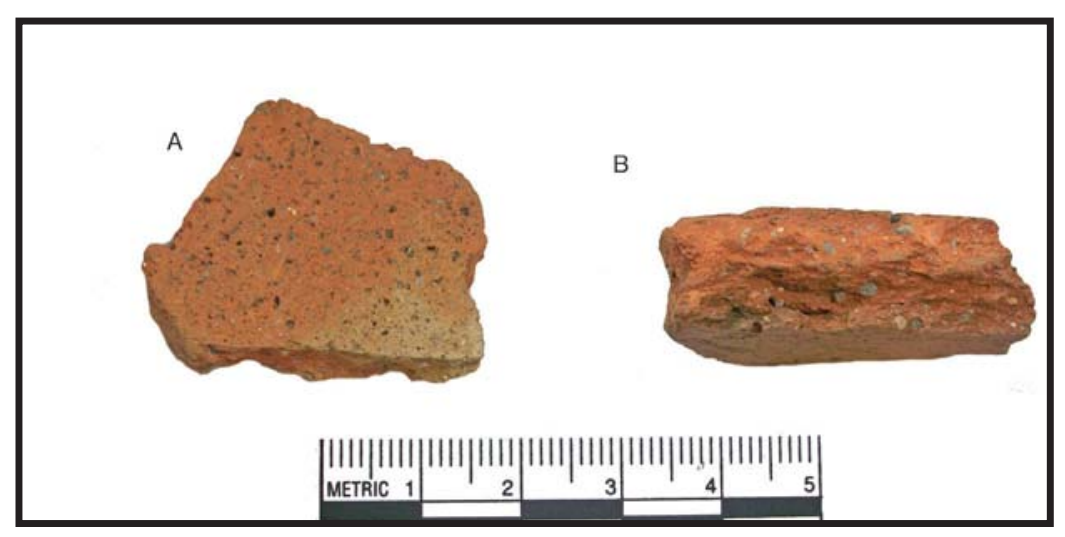

Figure 11. Limestone tempered sherds, identifiable by the grayish-white rounded particle that react slowly with hydrochloric acid and round voids from leeched particles. Both are from an unknown provenience at Mc12. 
Based on his work at sites along the Red River, including Roden (34Mc215), Rowland Clark (41RR77), and Bob Williams (41RR16), Perino (1980) created a basic seriation of changes in vessel forms from the Sanders through McCurtain phases. The seriation was used to assign the dates for the burial vessel assemblages shown in Table 2. These date ranges are relative estimates, given the dearth of secure context radiocarbon dates from Caddo sites in southeast Oklahoma. Based on this seriation of vessel changes, the McCurtain phase can be divided into three different periods, the early McCurtain phase, ( AD 1300-1450), the middle McCurtain phase ( AD 1450-1650), and the late McCurtain phase ( AD 1650+). Perino (1980:53) notes that jar shapes changed through time from a more squat, globular body shape to a more oblong, taller body (Figure 12a). Early jars frequently had four rim castellations and loop or strap handles. Over time, the castellations gradually disappeared and jar handles became lugs or closed handles. Jar body decoration also changes from dashed fingernail impressed lines to tool punctate lines to appliqued or engraved pendant triangles (Figure 13). The most obvious change in the bottle form occurred in the necks (Figure 12b), which shifted from relatively narrow and elongated to a squat spool-like form by the seventeenth century (Perino 1980:55). Based on the McDonald vessel assemblage, bottles appear to have shifted from a more globular to a low-shouldered version with a slanting upped body. During the Sanders phase, bowls were undecorated, with flat bottoms and tapered $\mathrm{v}$-shaped sides (Figure 12c). Early McCurtain short carinated bowls change over time from a vessel with a taller rim and angular shoulder and rim breaks to having a shorter rim and more curved profile. Many had scalloped rims. The tall bowls of the Late McCurtain (Figure 12d) phase are a variation on an earlier Sanders phase tall carinated bowl with a scalloped rim (Perino 1980:56). Over time, tall bowl rims changed from carinated to outflaring. Early fineware jars had squat bodies and high, castellated rims and four handles (Perino 1980:55). They were decorated on both rim and body fields. Over time, handles and rim castellations disappeared and bottle bodies became taller and more globular (Figure 12e).

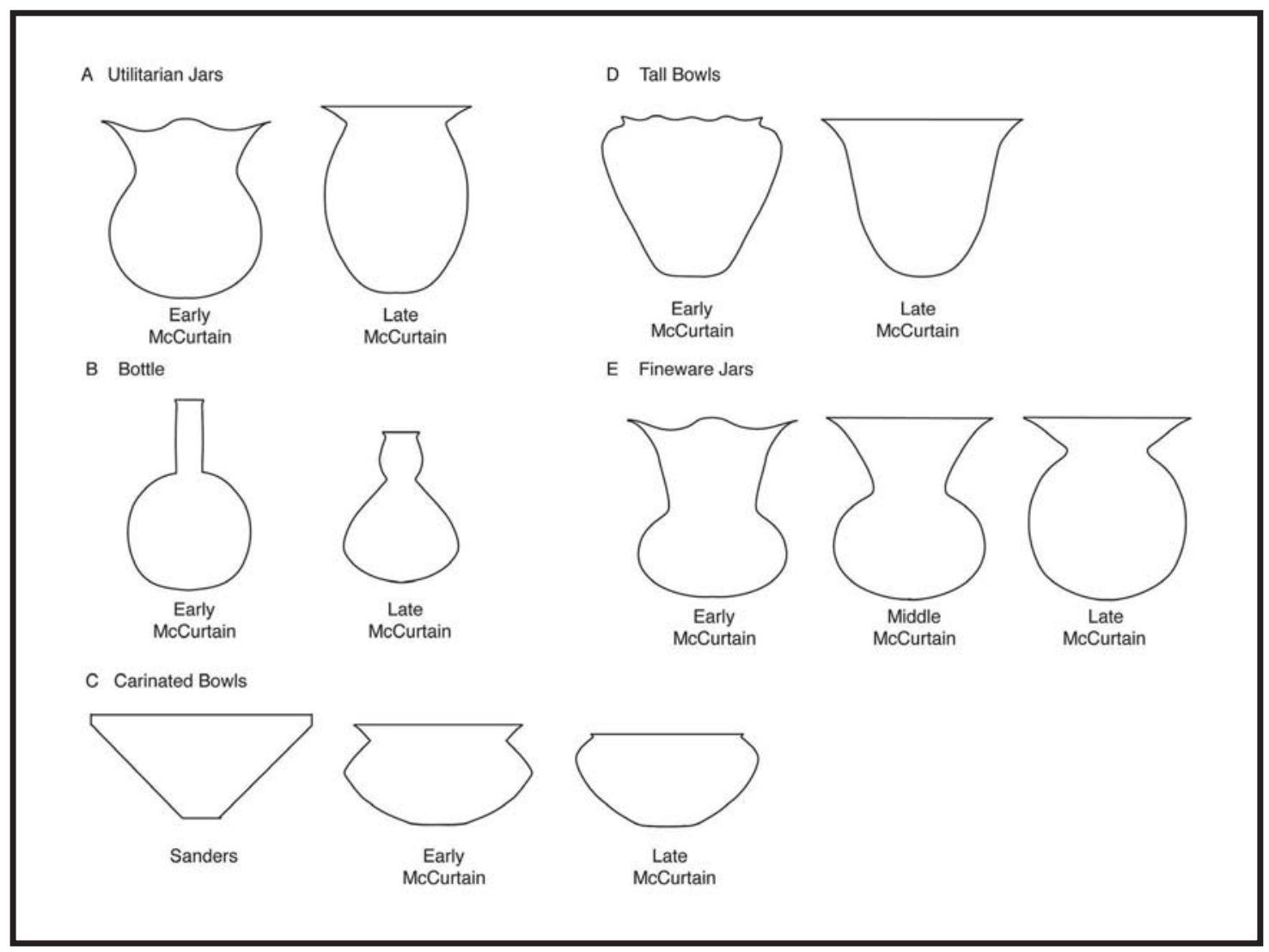

Figure 12. Changes in McCurtain phase vessel shapes over time. 


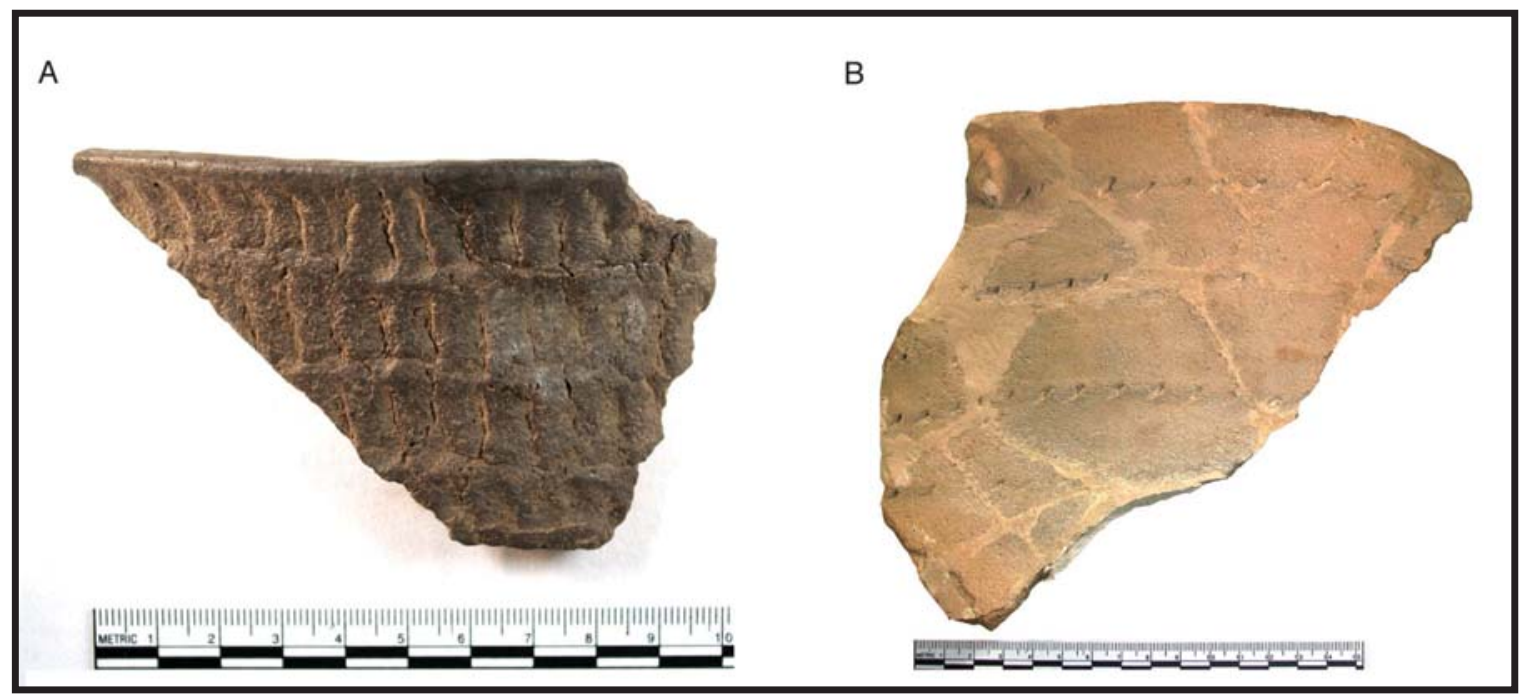

Figure 13. (A) Early McCurtain phase grog-tempered corrugated jar rim from the Mc11 midden and Middle/Late McCurtain phase. (B) Shell-tempered fingernail punctate rim from an unknown Mc12 provenience.

In addition to the Caddo component, 211 of the recovered sherds from the Mc11 midden and 13 sherds from the Mc11 test pits are thick sherds tempered with large chunks of grog indicative of an earlier Woodland occupation. Many of these sherds are thick bases and rims of flat bottomed jars, while others from vessel walls were identified by thickness and the presence of large chunks of grog, grit, and/or bone temper. The Woodland sherds represent $6.2 \%$ of the total ceramic assemblage. None are decorated, suggesting a date earlier in the Fourche Maline sequence, possibly the Fourche Maline I phase, spanning 300 B.C. to AD 1 (Leith 2011). The presence of a number of Gary type contracting stemmed points and a chipped stone hoe in the lithic tool assemblage discussed below are further evidence of a Woodland occupation at the site.

Excluding the identified Woodland sherds, the plain to decorated ratio (P:D) for the entire assemblage is 5.79. For the Mc11 midden, where the bulk of the sherd assemblage was recovered, the ratio is slightly higher at 6.11. Both are similar to the ratios calculated from data provided in Dowd's (2012:146-147) analysis of Caddo ceramic assemblages from sites in the Mountain Fork. The similarity in these ratios indicates that the McDonald collection is representative enough of the whole assemblage to draw some conclusions about the potters of the Glover drainage. The single-component fourteenth and fifteenth century assemblages at the fourteenth-century Woods Mound group and the fifteenth-century Biggham Creek site have P:D ratios of 5.21 and 5.5, almost equal to that of the McDonald site. This is a substantially higher ratio of decoration than has been reported at sites along the middle Red River in northeast Texas, where the P:D ratio is as high as 43.7:1 in Late Caddo contexts at the Roitsch site (Perttula 2008a; 2008b:489), and yet is a much lower ratio of decoration than at sites located farther south in east Texas (Perttula 2011:52). Based on these comparisons, Caddo groups living in the southern Ouachita Mountains decorated their utilitarian wares with greater frequency than their contemporaries living on the Coastal Plain along the Red River.

Perhaps more tellingly, while the potters in the southern Ouachita Mountains apparently made and used shell-tempered pottery, they did not adopt it to the extent of their middle Red River contemporaries. Perttula (2008b:349) reported that the decorated and rim assemblage at the Roitsch site along the Red River dating primarily between AD 1300-1450 with a smaller late occupation was nearly 90 percent shell-tempered. Based on the distribution of types, the occupations at Roitsch and McDonald appear to be roughly contemporaneous, but are distinctly different from one another on the basis of tempering and proportion of decorated sherds. Based on the comparison of ceramic data from the Red, Glover, and Mountain Fork drainage sites, the McCurtain 
phase designation as currently understood subsumes three clusters of Caddo sites whose potters worked in three distinct potting traditions. It is expected that the ongoing analysis of WPA-excavated assemblages from sites in southeast Oklahoma, particularly the ceramics from the Clement site, will help to better refine our understanding of the Glover drainage pottery style. Even without the completed analysis from the Clement site, the decorated sherds from the McDonald site help fill in some of the gaps in our understanding of Caddo occupations along the southwestern edges of the Ouachita Mountains.

\section{Finewares}

This category includes 292 engraved and red-slipped sherds from bowls and bottles, which represents 8.8\% of the total assemblage (Table 4). Red-slipped incised sherds and trailed sherds are also included in this category. Twelve of the engraved and 44 red-slipped sherds are shell tempered. The 200 plain red-slipped sherds and 20 red-slipped rims and bases, the majority of which are grog-tempered, are presumed to be plain sections of decorated Avery or Taylor Engraved or Sanders Plain vessels. Engraving motifs range from simple parallel lines to more complex portions of larger motifs. Curvilinear elements with added rays and/or engraved line filler are present on 26 of the sherds. Most can be identified as Avery, Ripley, Taylor Engraved motifs (Figure 14). Two additional sherds also shown in Figure 14 are from Simms Engraved carinated bowls. A single sherd from a carinated bowl also seen in Figure 14 and two of the burial vessels (B21-5\&6) are examples of Clark Engraved, a type created by Perino (1980:57, Figures 13 and 14) based on pottery from the Rowland Clark site, is dated to AD 1300 to 1450. A grog-tempered red-slipped sherd with paired nodes typical of Maxey Noded Redware from an unknown context at Mc12 is the only sherd from a Sanders fineware type (Figure 15).

Table 4. Decorative Modes in the McDonald Assemblage

\begin{tabular}{|c|c|c|c|c|}
\hline Decorative Mode & Mc11 Midden & $\begin{array}{c}\text { Mc11 Test Pits/ } \\
\text { Surface }\end{array}$ & Mc12 & Total \\
\hline Engraved & 49 & 6 & 2 & 57 \\
\hline Engraved/Incised & 4 & 1 & 0 & 5 \\
\hline Incised & 35 & 27 & 7 & 69 \\
\hline Red-slipped Incised & 6 & 2 & 0 & 8 \\
\hline Incised/Fingernail Impressed & 33 & 3 & 1 & 37 \\
\hline Incised/Applique & 10 & 0 & 2 & 12 \\
\hline Incised/Applique/Fingernail Impressed & 13 & 0 & 0 & 13 \\
\hline Incised/Applique/Engraved & 1 & 0 & 0 & 1 \\
\hline Incised/Fingernail Impressed/Handle & 2 & 0 & 0 & 2 \\
\hline Fingernail Impressed & 97 & 12 & 11 & 120 \\
\hline Fingernail Impressed/Applique & 37 & 4 & 2 & 43 \\
\hline Fingernail Impressed/Applique/Handle & 0 & 1 & 0 & 1 \\
\hline Punctate & 14 & 0 & 0 & 14 \\
\hline Red-slipped Punctate & 1 & 0 & 0 & 1 \\
\hline Applique & 39 & 10 & 2 & 51 \\
\hline Red-slipped Applique & 1 & 0 & 0 & 1 \\
\hline Handles & 2 & 0 & 0 & 2 \\
\hline Noded & 0 & 2 & 2 & 4 \\
\hline Smoothed Ridge Pinched & 37 & 7 & 1 & 45 \\
\hline Smoothed Ridge Pinched/Applique & 10 & 0 & 0 & 10 \\
\hline Smoothed Ridge Pinched/Fingnernail Impressed & 4 & 0 & 0 & 4 \\
\hline Smoothed Ridge Pinched/Handle & 4 & 0 & 0 & 4 \\
\hline Smoothed Ridge Pinched/Applique/Incised & 0 & 0 & 1 & 1 \\
\hline Eroded & 3 & 0 & 0 & 3 \\
\hline Total & 402 & 75 & 31 & 508 \\
\hline
\end{tabular}




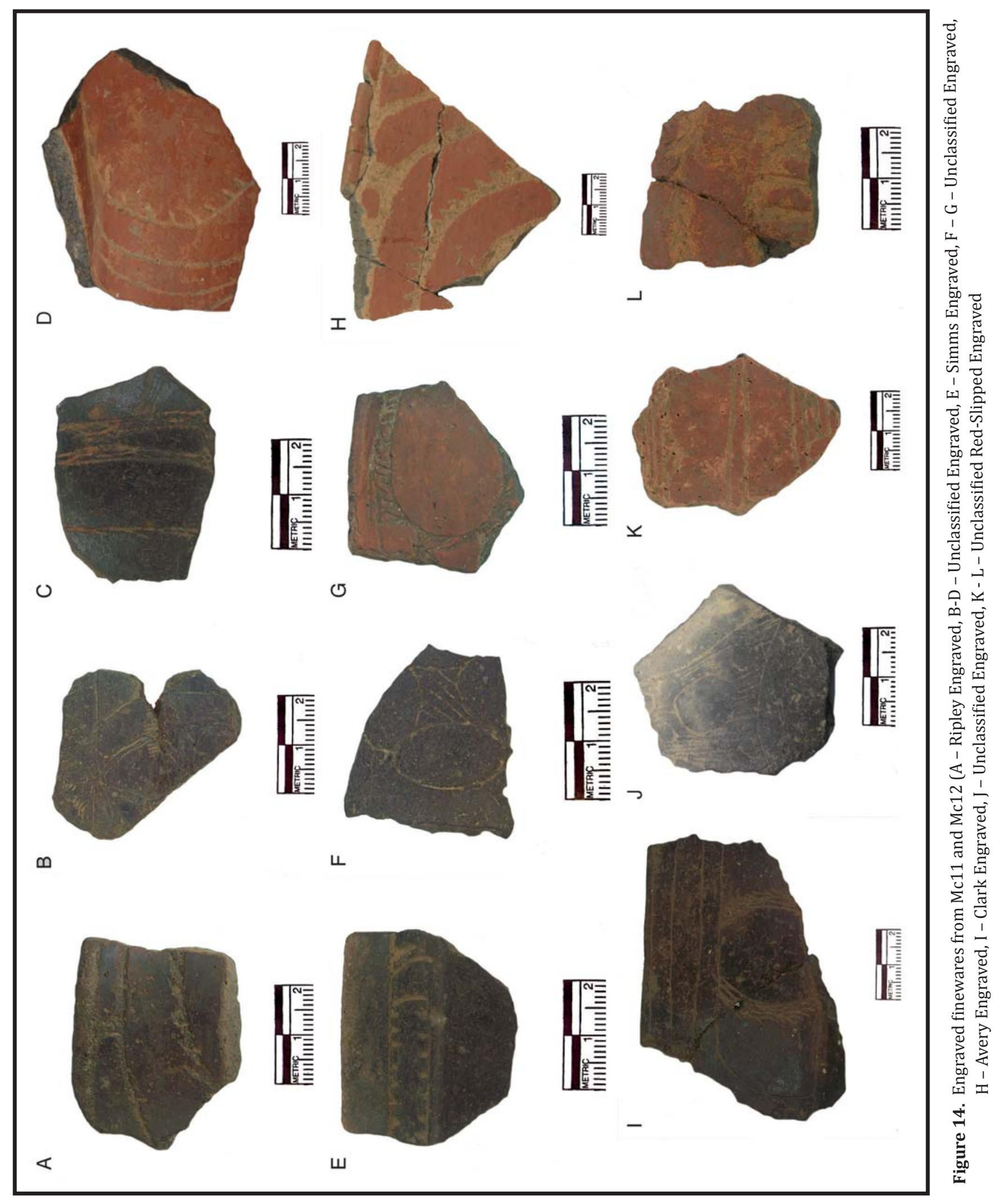




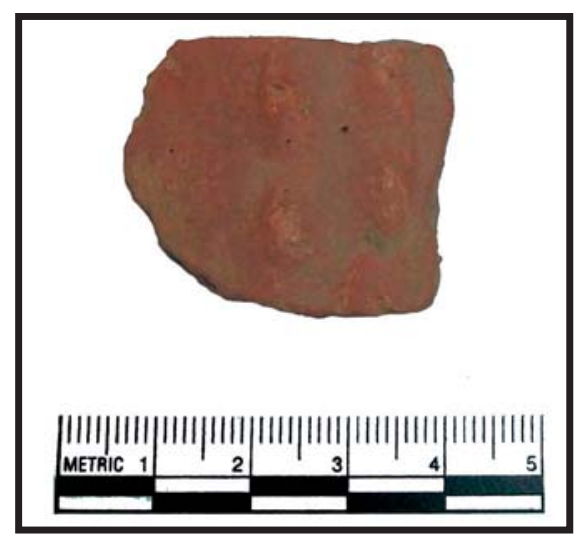

Figure 15. Sanders phase Maxey Noded Redware bottle body fragment from an unknown context at Mc12.

While three Hudson Engraved bottles (B15-5, B18-7, and B24-1) are present in the burial vessel assemblage from the Mc11 midden, no sherds of this type were recovered. As Perttula (2008b:355) noted, Hudson Engraved is a marker of post-AD 1650 occupation along the Middle Red River. A single Keno Trailed vessel (B2-1) and three shell-tempered Keno Trailed sherds (Figure 16) were recovered from the Mc11 cemetery and midden, which further supports a small seventeenth century occupation. A shell-tempered redslipped Avery Engraved flaring rim, globular bodied jar with pendant scrolls in the burial assemblage (B3-1) also likely dates to this later occupation. Perino (1981:36, Figure 20A) depicts a similarly decorated vessel from a burial with European trade goods excavated at the Roden site.

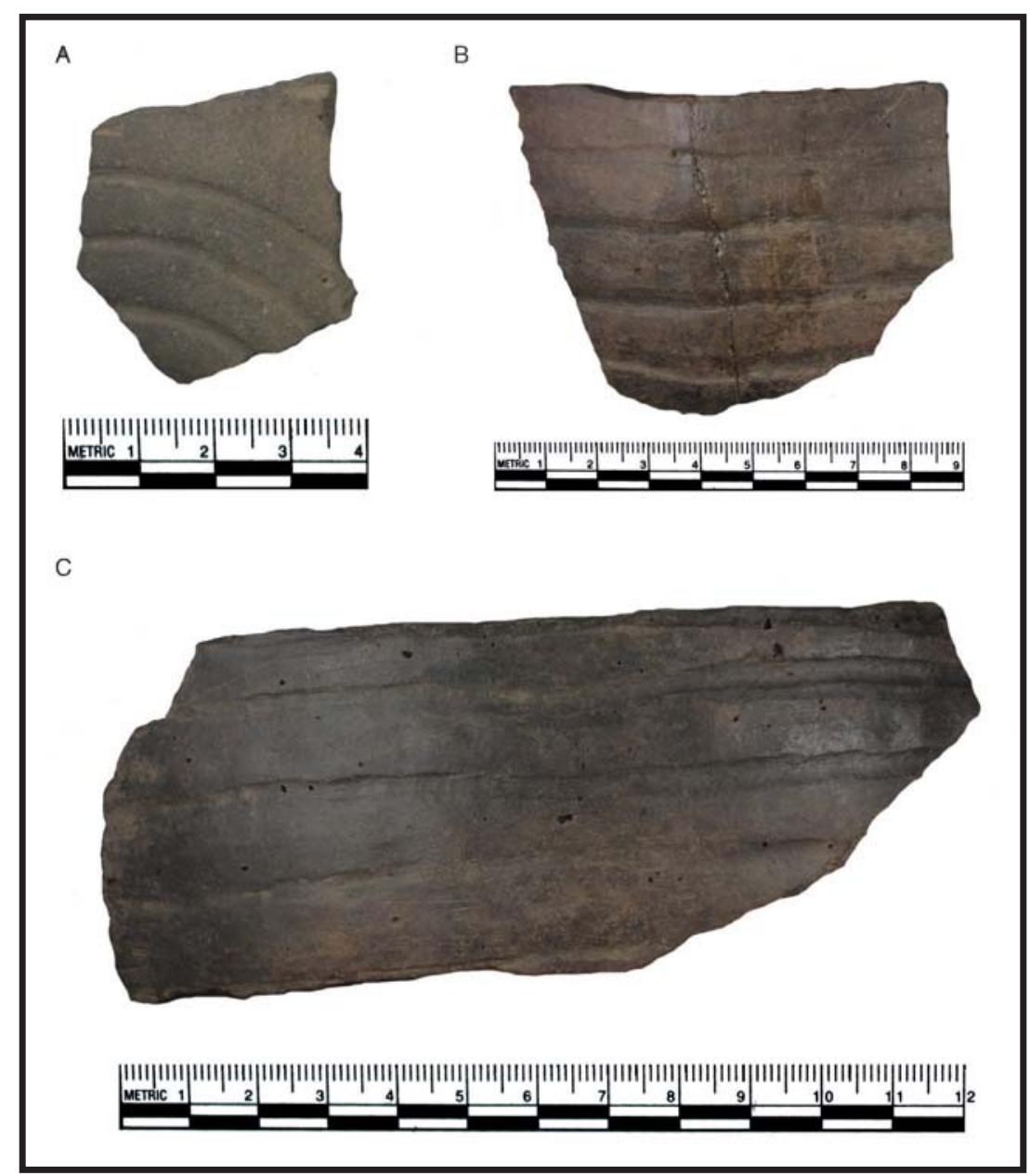

Figure 16. Keno Trailed sherds recovered from the Mc11 midden. 


\section{Utilitarian Wares}

The utilitarian assemblage includes sherds associated with early, middle, and late decorative traditions of the McCurtain phase, reflecting the relatively long occupation at and around the McDonald site. A greater proportion of the utilitarian wares are associated with the Middle and Late McCurtain phase occupation than is true for the fineware assemblage. The most common decorative technique for utilitarian jars is fingernail impressions, which occurred on the bodies of jars during earlier periods and on later jar rims (see Table 4). Fingernail punctations occur along with applique and incising on jar bodies, and are commonly paired with a corrugated rim on early McCurtain phase vessels. The configuration of incised and fingernail punctate lines on jar bodies has a wide degree of variation. The line patterns may be vertical, horizontal, perpendicular, arched, or diagonal (Figure 17). The second most common decorative method is incising, which is found on in horizontal bands on the bodies of corrugated jars, in barred diagonal lines, cross hatching, parallel horizontal and vertical lines, and diamond configurations on jar bodies (Figure 18). Several incised sherds from Mc12 are from Canton Incised jar rims, meaning they likely date to the very limited Sanders phase occupation. When only jar rims were recovered, the most common decorative method is corrugating. On late jars, fingernail impressions are the only decorative mode on certain jar rims, which are typically shell-tempered shorter than their corrugated counterparts. Later utilitarian sherds are also identified by the presence of pendant triangle patterns made from ticked ridges of applied clay on the bodies of jars (Figure 19). One unusual jar sherd recovered from Mc12 has incised interconnected festoon motifs with diagonal lines above and rectangular incising below (Figure 20).

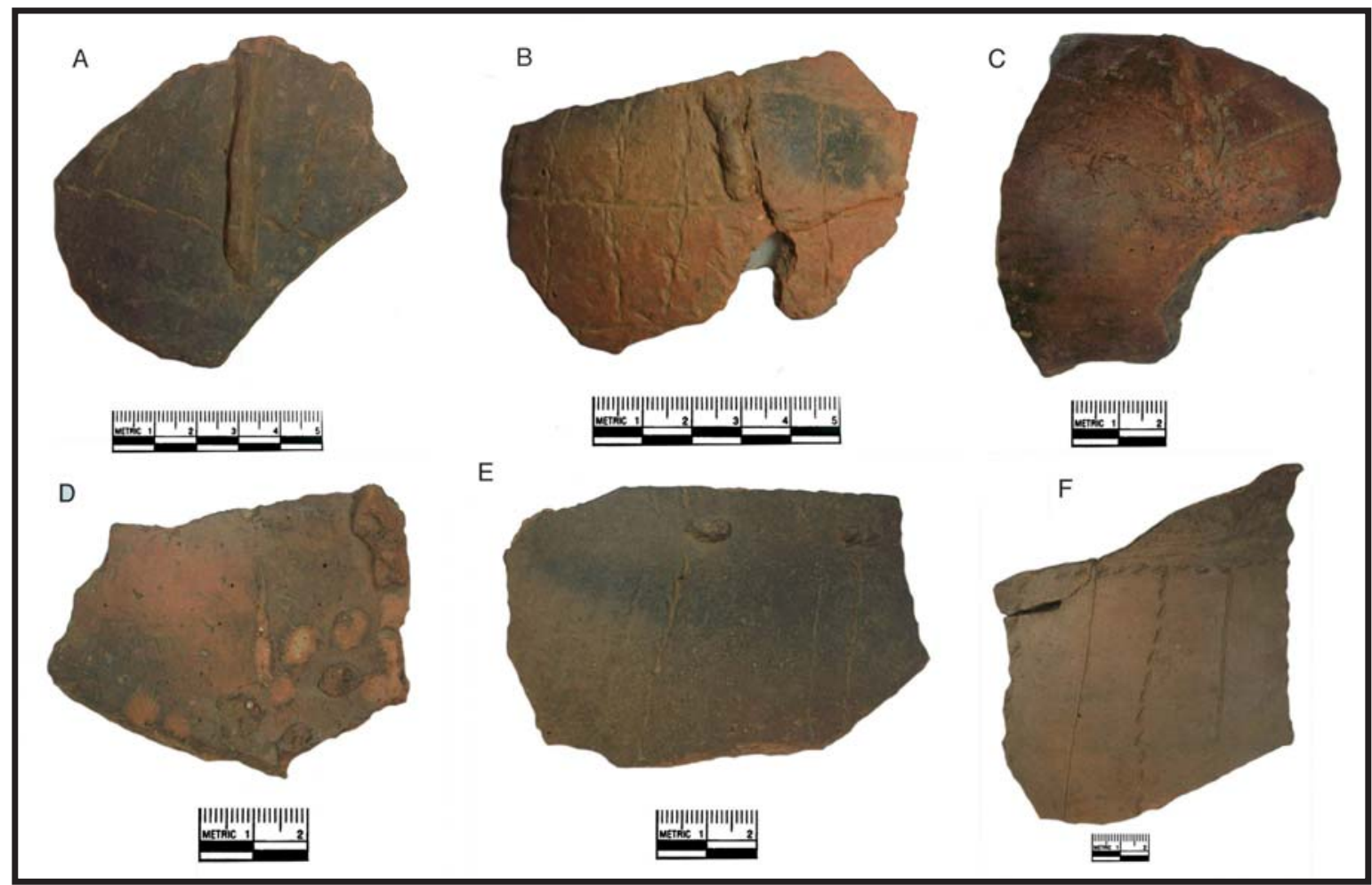

Figure 17. Utilitarian jar body sherds from the Mc11 midden and Mc12 that show the variety of incising, applique, and fingernail punctation configurations in the assemblage. 


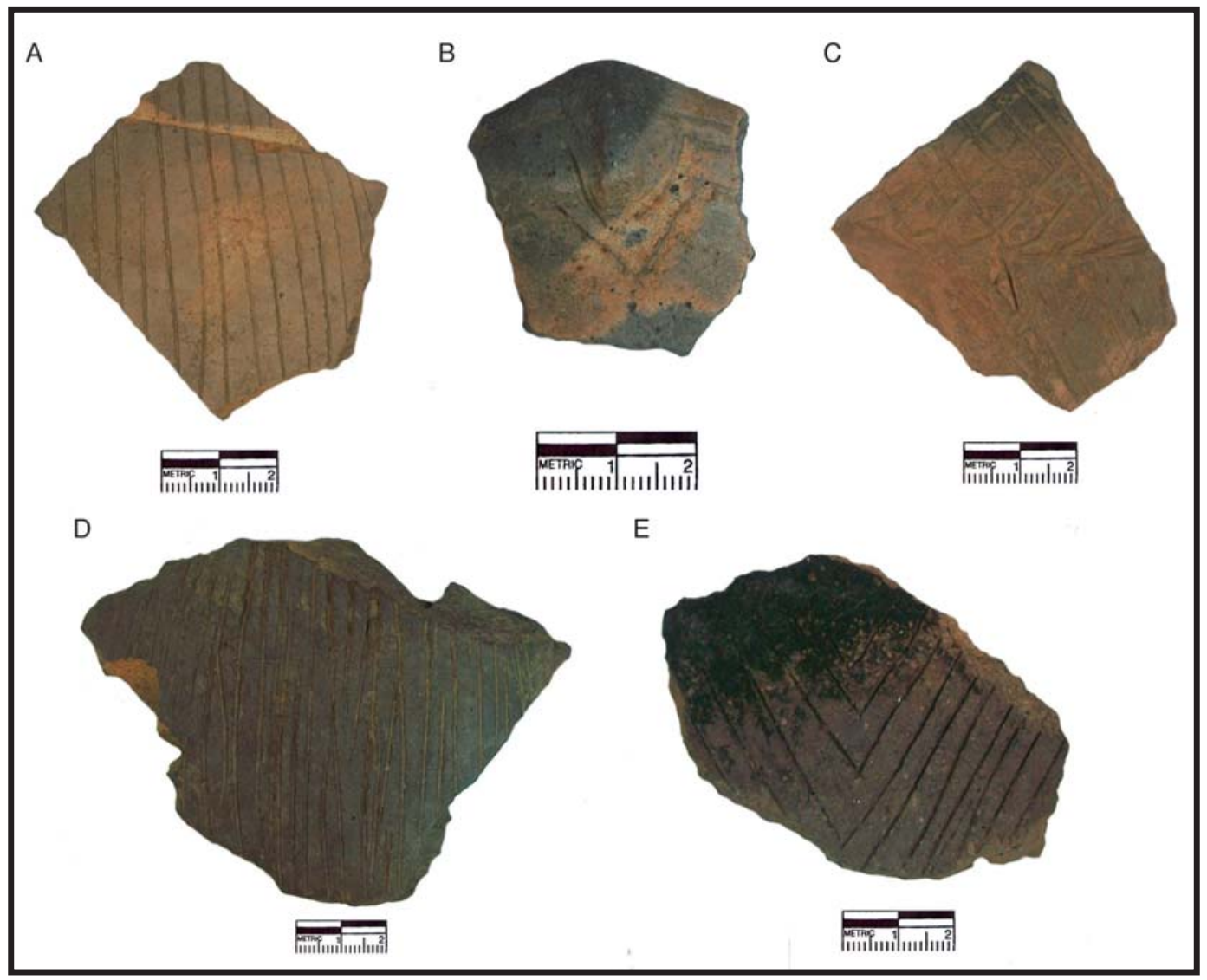

Figure 18. Jar body and rim sherds decorated with a variety of incising motifs. (A - grog temper, B - grog/ limestone temper, C, D, E, F - grog temper)

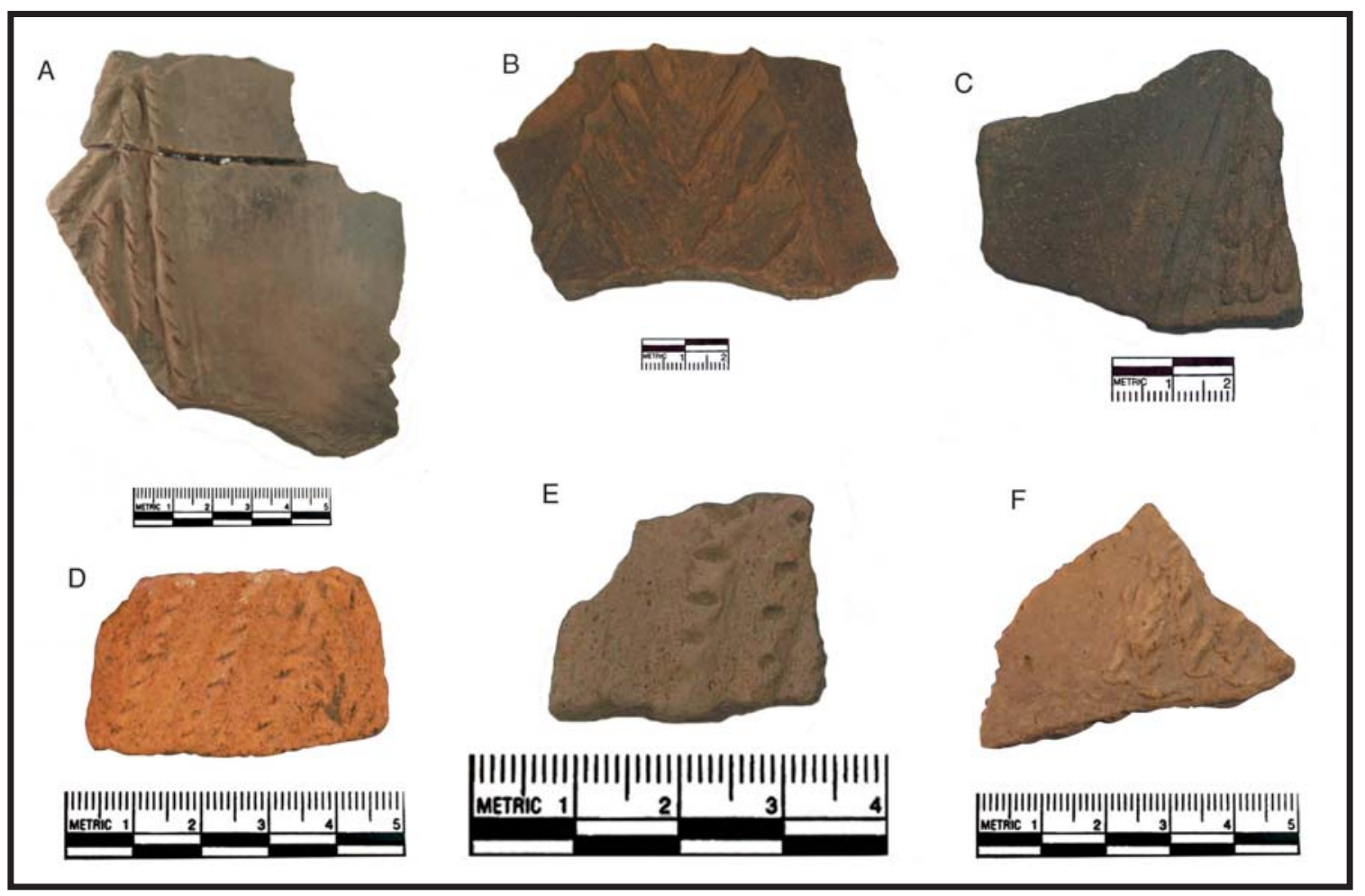

Figure 19. A variety of forms of appliqued triangles found on the bodies of utilitarian jars. (A, B, C - grog temper, D, E - shell temper, F - grog/limestone temper) 


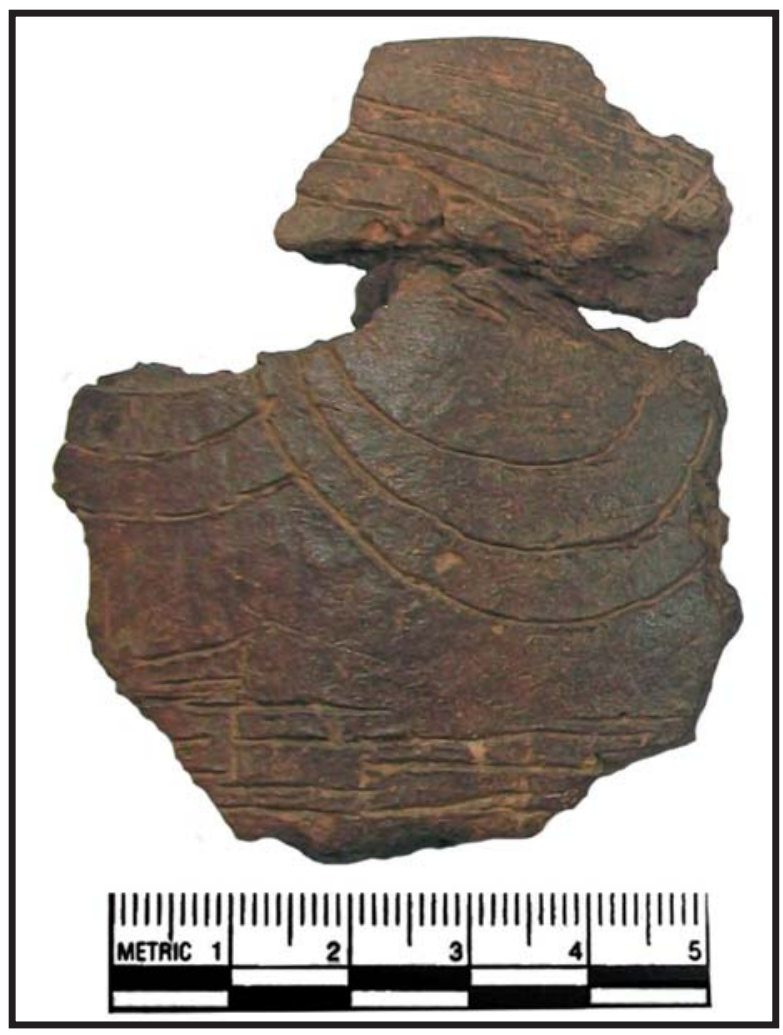

Figure 20. Grog-tempered jar sherd decorated with a variety of incising motifs recovered from Stake 3:3 at Mc12.

\section{Pipes}

Fragments of five pipes were recovered from the Mc11 midden. This is a relatively low number when compared with other contemporaneous sites (see Perino 1980, 1981, 1983, 1994 and Perttula 2008b:356). Only two (Figure 21) are large enough to be identified via Hoffman's (1967) typology. Both are from elbow pipes, which were first made in the Sanders phase and continued to be made through the McCurtain phase.

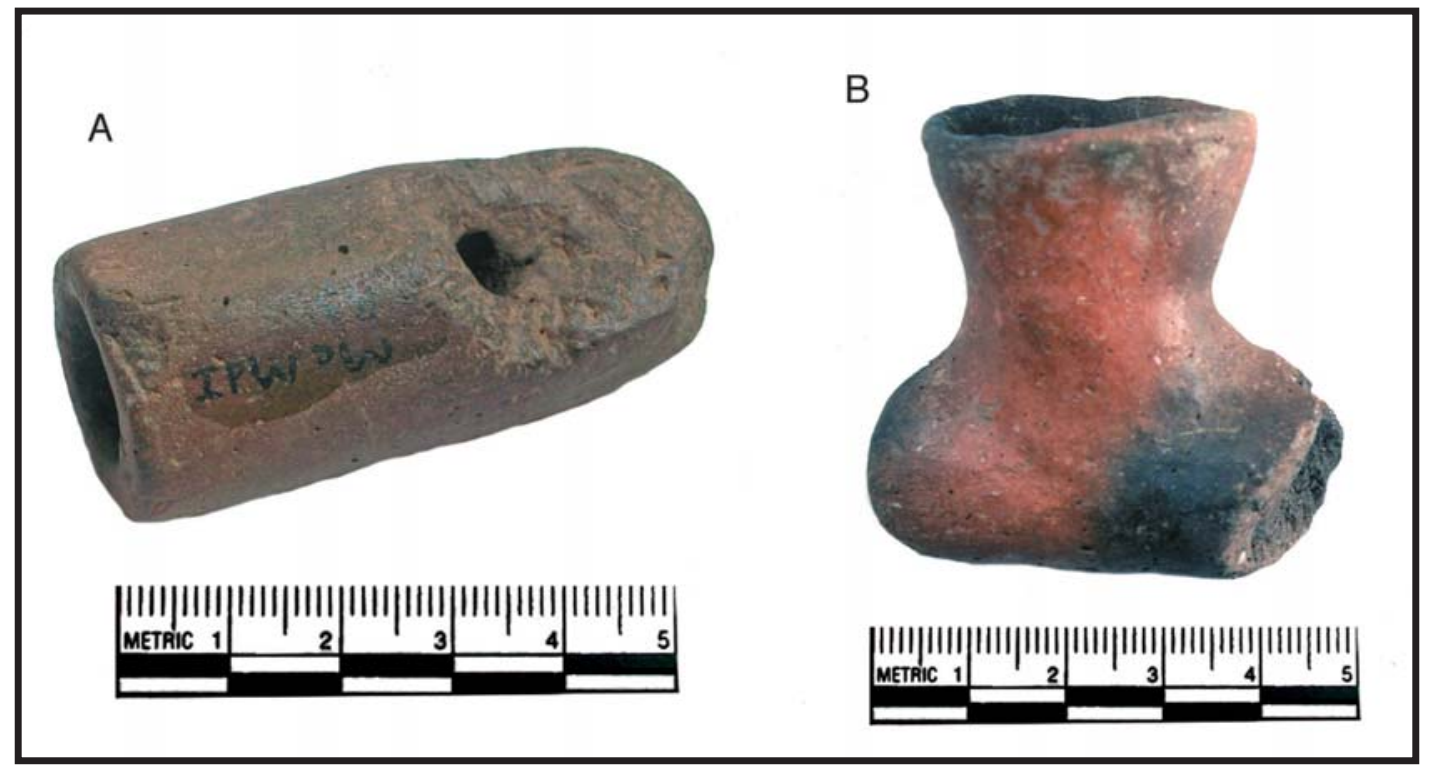

Figure 21. Elbow pipe bowls recovered from the Mc11 midden. 


\section{Ceramic Distributions at Mc11 and Mc12}

The use of a 5-x-5-foot excavation grid by the WPA workers facilitated the creation of ceramic distribution maps for the midden area. The excavated midden area is relatively small, measuring only $30-\mathrm{x}-30$ $\mathrm{m}$, with a $25-\mathrm{x}-15 \mathrm{~m}$ extension. The cumulative distribution map of pottery in the midden shows three large concentrations of ceramics in several areas of the site (Figure 22). Each concentration is confined to a 5-x-5foot square, which suggests crews encountered features, such as refuse pits, in these areas. Unfortunately, no features are mentioned in the notes, and the concentrations are attributed to three different levels. A broader and lower density concentration of materials is present in columns 5-7, rows 9-12. The distributions of shelltempered sherds and finewares show concentrations in different areas of the site (Figure 23). These may reflect shifts in site use over time. At the outset, I had hoped to look at the distribution of sherds and temper classes by level to determine whether the McCurtain phase occupation was at all stratified by sub-phase. Unfortunately, roughly 75 percent of the midden sherds are from Levels 1 and 2, which at 0-6" and 6-12", places them within the plowzone. The distribution of Fourche Maline sherds is different from the overall pottery distribution (Figure 24). The low-density Woodland occupation is confined primarily to the northeastern and eastern portions of the midden.

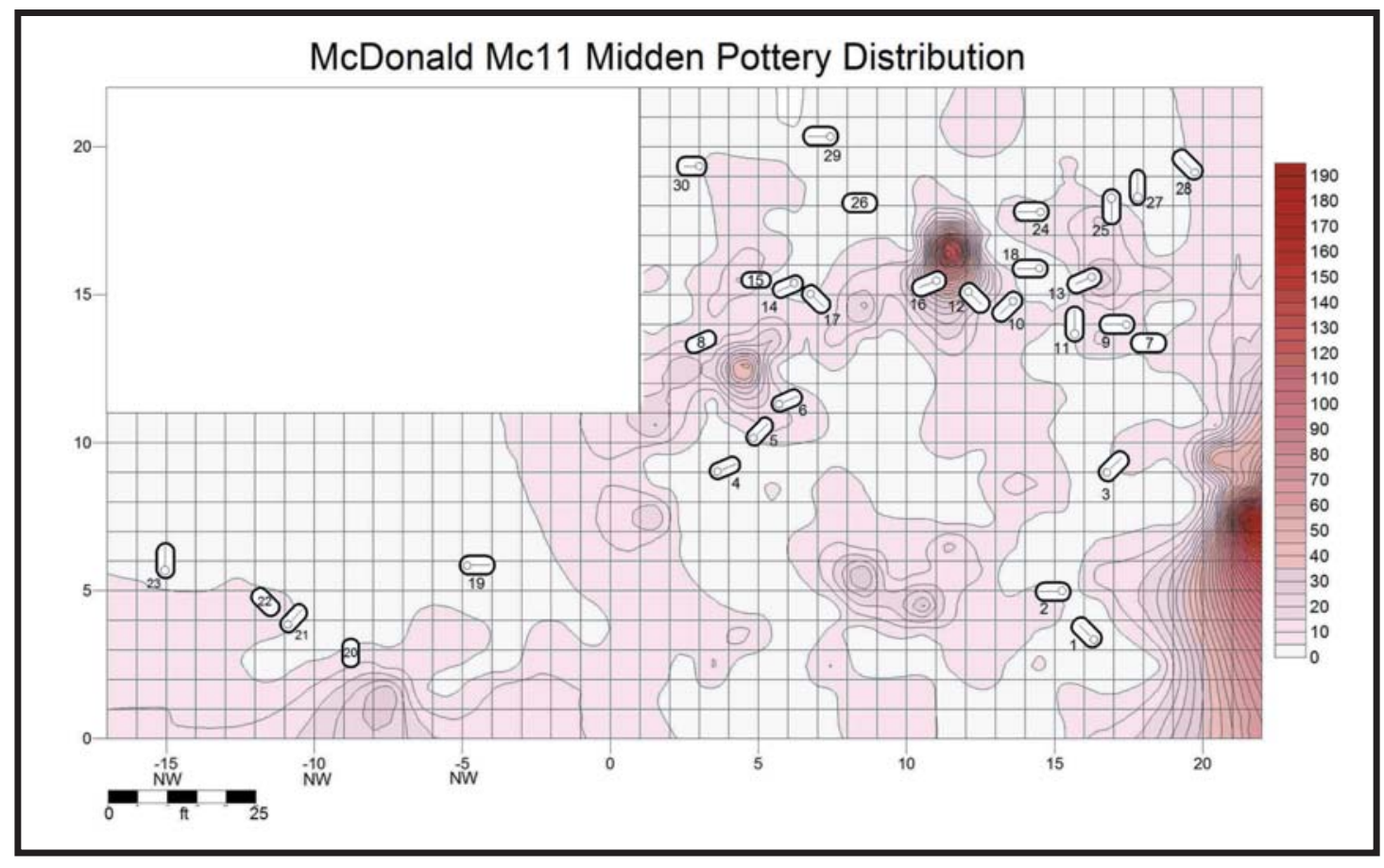

Figure 22. Density contour of sherds by count in the Mc11 midden.

The sherds from the Mc12 portion of the site, particularly from House 1, are overwhelmingly utilitarian wares. The only finewares recovered from the interior of the house are two engraved sherds and the two miniature vessels. The recovered sherds are from at least three bowls, two are plain and one of the engraved sherds is decorated with horizontal parallel lines below the lip. Rims and body sherds from at least five jars were recovered from the house floor. All of the house floor sherds are consistent with Early McCurtain phase vessel forms and decorative treatments, suggesting the house dates between AD 1300-1450. Apart from the pottery on the house floor, the remaining provenienced Mc12 sherd collection is attributed to only two units. These sherds are from a later McCurtain phase occupation, based on the presence of multiple utilitarian jars with applique triangle patterns on the body and shell tempered sherds with bands of fingernail punctations encircling the rim. The unprovenienced sherds from Mc12, frustratingly assigned to a provenience listed as "unknown", include the only Sanders phase sherds, examples of Maxey Noded Redware, Sanders Engraved, and Canton Incised. Given large size of the artifact scatter and the long occupation sequence, it is possible that the 
locations of fields and households on the McDonald terrace shifted over time, and Sanders phase households are located elsewhere. It may also be the case that there was no substantial Sanders phase occupation. Survey along the Red River has demonstrated Caddo occupations dating between AD 900-1300 tend to be clustered around mound sites, and expansion to broad river terraces only occurred when the Caddo began intensively cultivating maize after AD 1300 (Perttula 2008b:267-268).

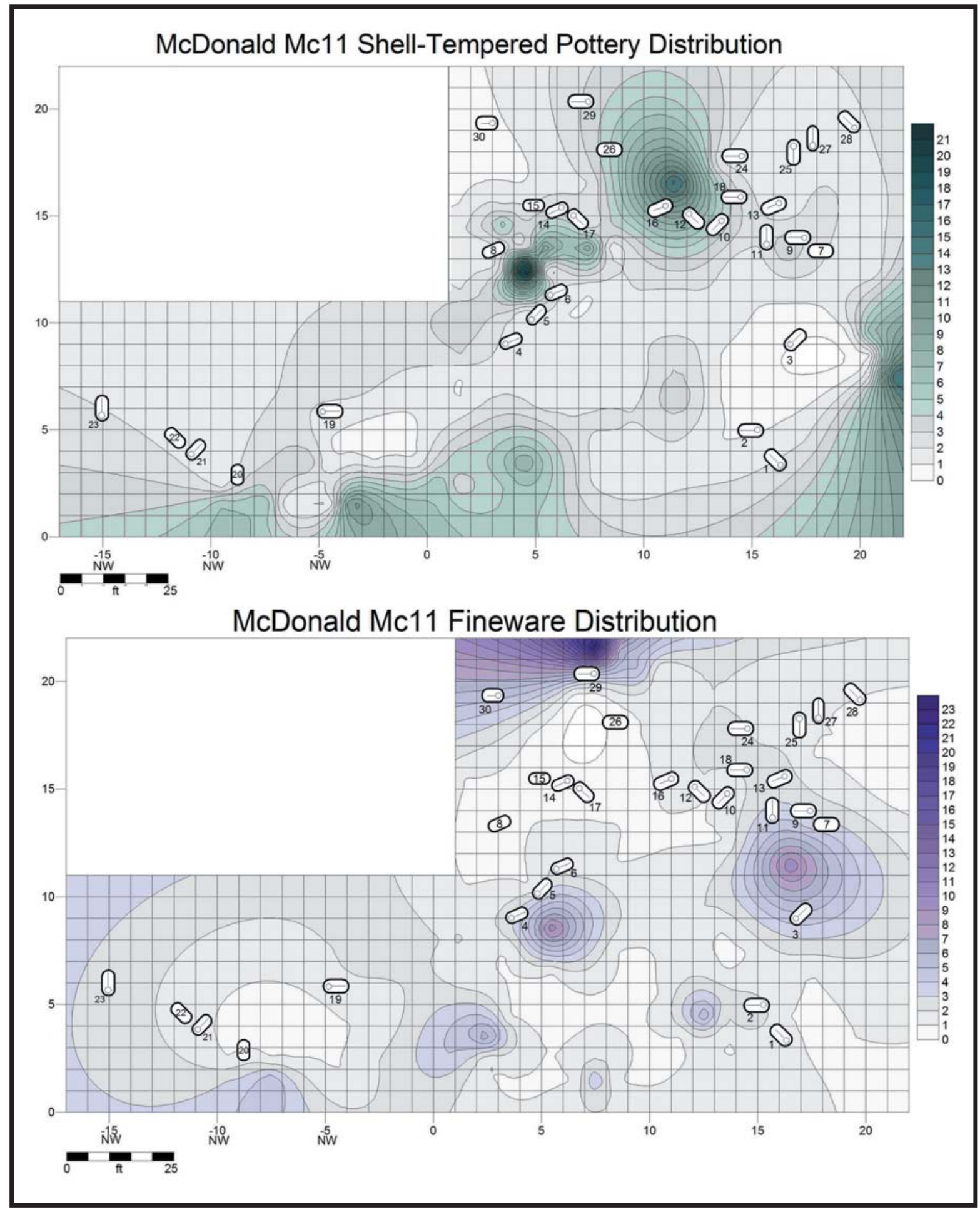

Figure 23. (Top) Density contour of shell-tempered sherds by count in the Mc11 midden. (Bottom) Density contour of fineware sherds by count in the Mc12 midden. 


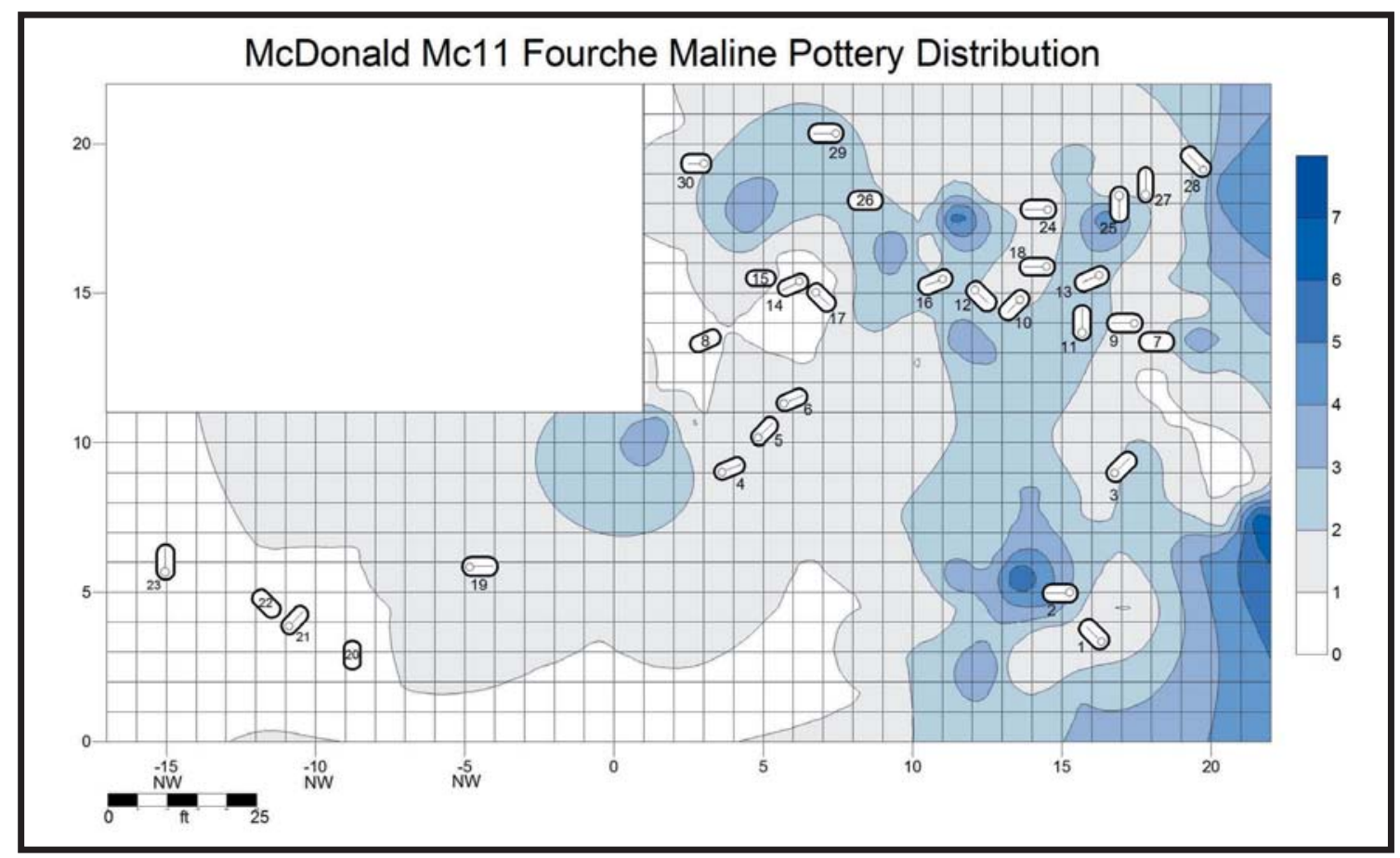

Figure 24. Density contour of Fourche Maline (Woodland) sherds in the Mc11 midden.

\section{Lithic Artifacts}

All of the 211 lithic artifacts in the McDonald collection were made from locally-available or nearby stone sources, listed in Table 5. Because of the underlying geology of the Ouachita Mountains, knappable stone is abundant in the site area, available as gravels in the nearby Glover, or at outcrops upstream in the Ouachitas. Because the WPA did not screen excavated soil, the chipped stone assemblage consists largely of finished tools, a few large utilized flakes, and no debitage. Therefore, it is impossible to discuss knapping strategies or other technological aspects of stone tool production at McDonald in any great detail. The assemblage of arrow points is also small, which is unfortunate, since the types of arrow points provide another method of refining site chronology. Only seven small arrow points, consisting of two novaculite Agees, one Big Fork chert Alba, two novaculite Massard C's, and one John's Valley chert Scallorn. Following Brown's (1996) Spiro seriation, the Agee and Massard C points date between AD 1000 and 1250, meaning they may be associated with the small Sanders phase occupation. Alba and Scallorn points are common on early McCurtain phase sites (Bruseth 1998:60). None of the unnotched point triangular point types typically associated with later McCurtain phase occupations (Perttula 2008b:356) were recovered, although this may be due to the selective recovery process.

Table 5. Lithic Material Types

\begin{tabular}{|c|c|c|}
\hline Material Type & Count & Percentage \\
\hline Novaculite & 46 & 21.8 \\
\hline Quartzite & 38 & 18.0 \\
\hline Red River Jasper & 32 & 15.2 \\
\hline Big Fork Chert & 29 & 13.7 \\
\hline Argillite & 27 & 12.8 \\
\hline Johns Valley Chert & 21 & 10.0 \\
\hline Chalcedony & 6 & 2.8 \\
\hline Quartz & 5 & 2.4 \\
\hline Antlers Gravel & 5 & 2.4 \\
\hline Green Chert & 2 & 0.9 \\
\hline Total & 211 & 100.0 \\
\hline
\end{tabular}


The overwhelming majority of hafted bifaces $(n=47)$ recovered from the site are contracting stemmed Gary points. They are made from every available knappable stone, and identifiable examples of all three varieties described by Schambach (1982), vars. gary $(\mathrm{n}=12)$, leflore $(\mathrm{n}=8)$, and camden $(\mathrm{n}=13)$, exist in the collection. The presence of the earliest form indicates the site was used, probably intermittently, during the Late Archaic (1500-300 B.C.) as well as during the Woodland. Several other Late Archaic points are present in the assemblage, including two corner-notched and four straight-stemmed points. All but one are made from locally available materials. One of the straight-stemmed points is made from Antlers Gravel, which outcrops on the western edge of the Ouachita Mountains, roughly 50 miles from the Glover drainage.

Several other bifacially-worked tools in the collection are worth noting. The first is a quartzite, leafshaped biface, mainly of interest because it was recovered from cache pit C1 along with the reworked bowl and hunks of quartz at Mc12 (Figure 25a). Four Johns Valley chert bifacial tools were recovered from the floor of House 1 (Figure 25b). This includes the base of a Gary var. Gary point, two reworked knives, and a scraper. A biface tool recovered from Stake 19:9 in the Mc11 midden is made from an unusual mottled green chert that outcrops along the Kiamichi River (Figure 25c). Other tools in the collection include two drills, a graver, and unifacial and bifacial scrapers.

Sixteen ground and flaked whole and partial stone celts are present in the assemblage. They were made by removing flakes roughly along the margins of oblong pieces of river gravels and then grinding both ends (Figure 26a). Celts were made from argillite $(n=9)$, quartzite $(n=5)$, and sandstone $(n=2)$. Two large argillite flakes that appear to have been knocked off of a single celt also were recovered. These tools are evenly distributed across the midden zone. One chipped sandstone hoe and another possible hoe also were recovered from the Mc11 midden (Figure 26b). Five nutting stones, made from sandstone (n=2), quartzite ( $n=2)$, and phyllite $(n=1)$ are in the collection. One of the quartzite stones was recovered adjacent to the hearth in House 1. Three flat groundstone fragments of phyllite from the Mc11 midden appear to be portions of stone gorgets. Finally, two large chunks of bright red pigment-quality hematite were recovered from the Mc11 midden.

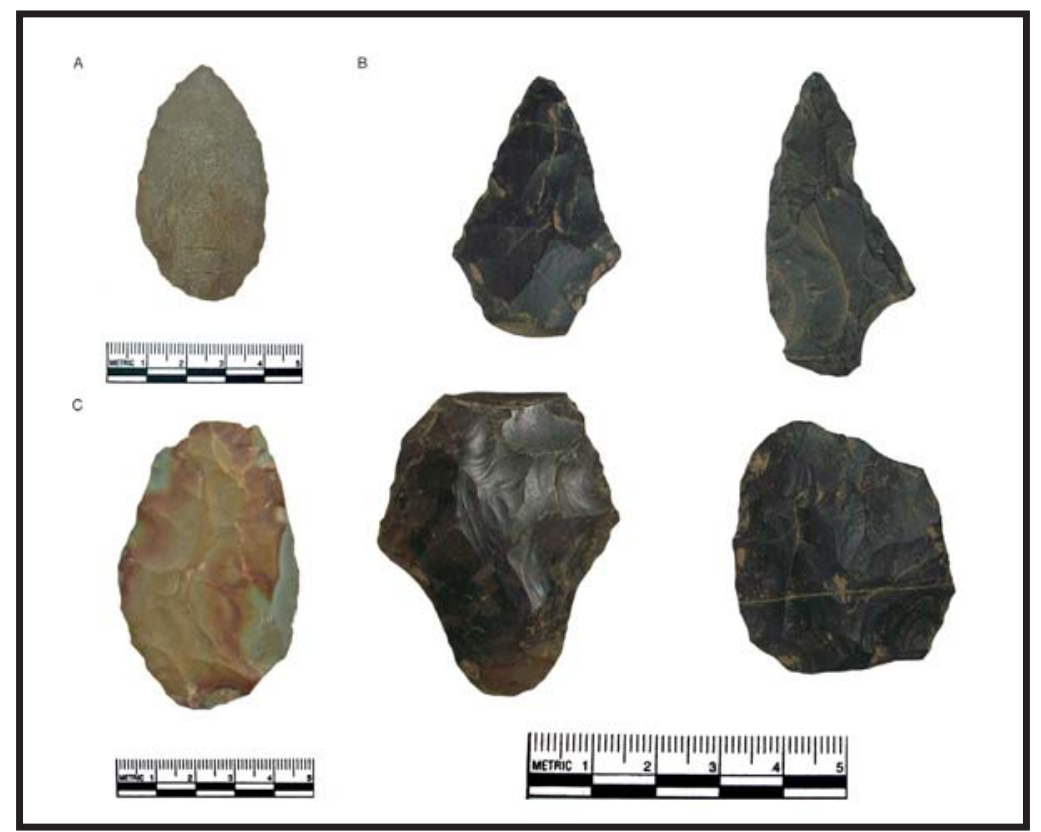

Figure 25. Selected stone tools in the artifact assemblage (A - Leaf-shaped quartzite biface found in the fill of Cache Pit 1 at Mc12, B - Four Johns Valley chert Bifaces/tools recovered from the floor of House 1, C - Green and gold chert biface recovered from an unknown context at Mc11. 

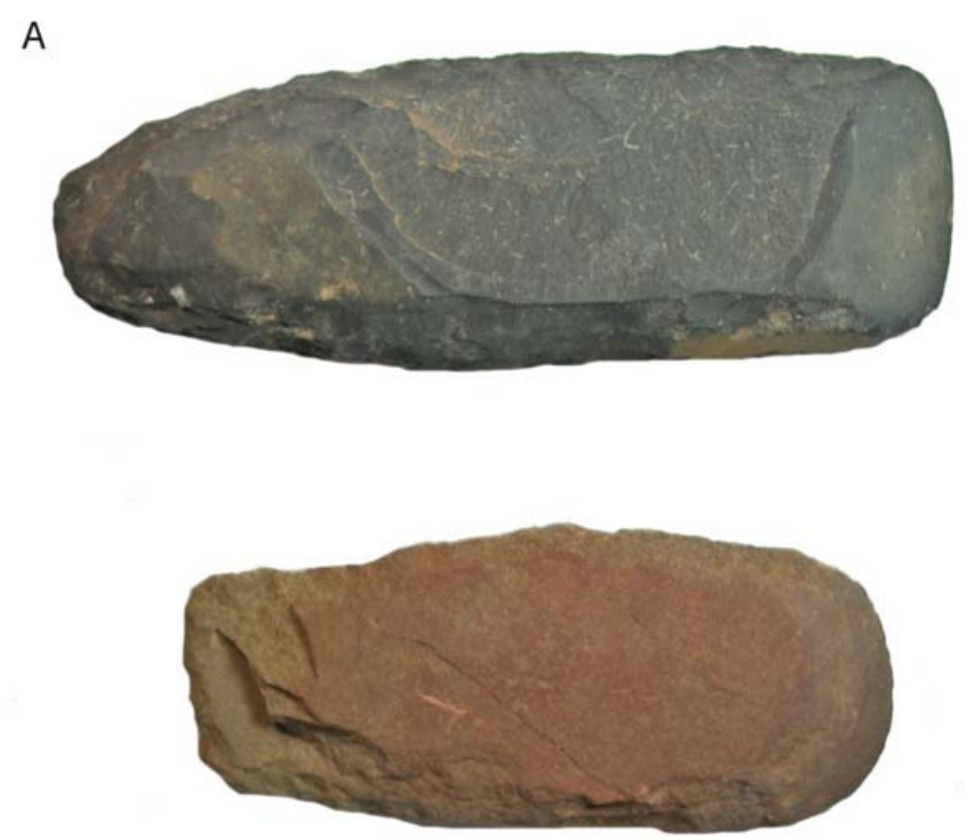

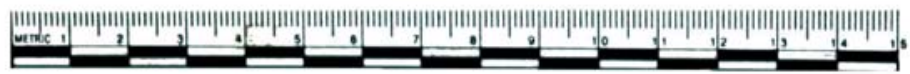

B

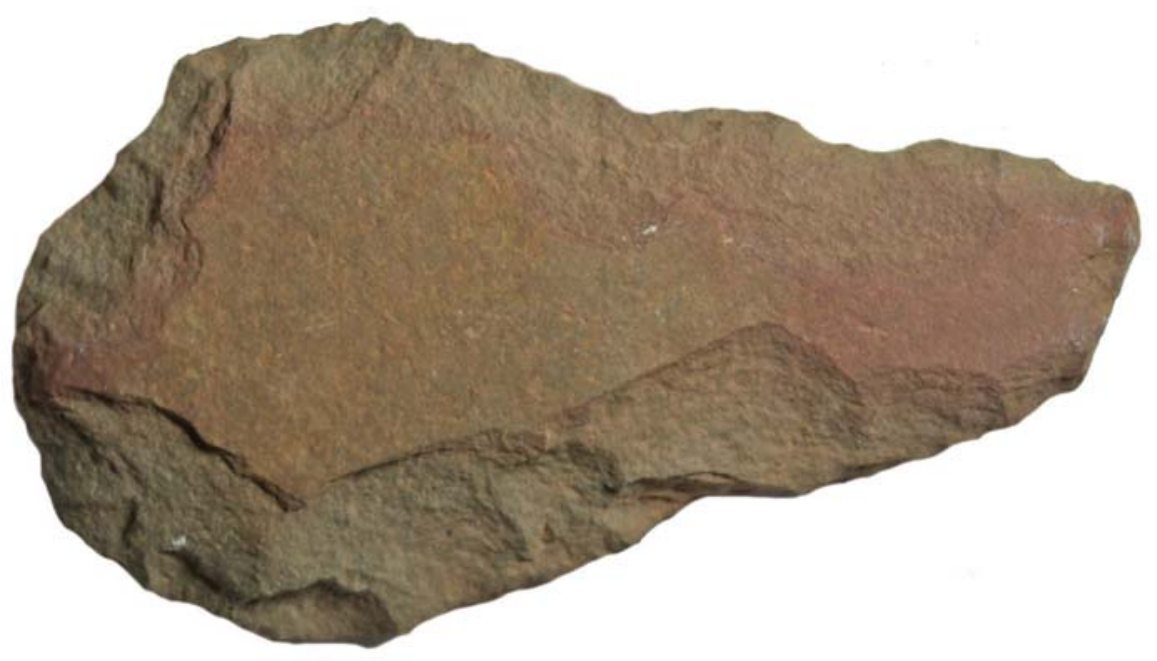

|II!|

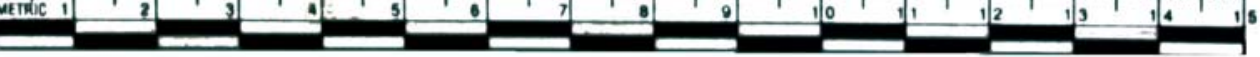

Figure 26. A - Ground and battered celts from the Mc11 midden, B - Chipped stone hoe from A3 at Mc12. 


\section{Reevaluating the McDonald Site}

Before beginning this reanalysis, the McDonald site was viewed as a small Caddo farmstead with an associated midden and cemetery. After finding Baerreis' report and analyzing the artifacts, a different picture of the site has emerged. The single structure at Mc12 and excavated midden area at Mc11 are part of a much larger occupation complex that spans nearly a mile along a bend in the Glover. McDonald is at the northern edge of a chain of Caddo occupations that sprawl across the terraces of the lower Glover drainage. Upstream, above McDonald, the Glover is constricted by the Ouachita Mountains and recorded sites are smaller single household settlements on narrow terraces. The artifact analysis has demonstrated that occupation at and around the McDonald site has a considerable time depth, beginning with periodic use during the Late Archaic and ending with permanent settlement lasting through the seventeenth century AD. This late occupation date is somewhat surprising, since it has been assumed that smaller sites in the Ouachita Mountains like McDonald were abandoned as a result of the exceptional drought that occurred in the late fourteenth and early fifteenth century (e.g. Perttula 2012:103).

This analysis is also a beginning step in understanding the relationship between outlying sites like McDonald and the mound sites along the Glover. The assemblage in the McDonald midden and household is comprised primarily of utilitarian vessels and stone artifacts made from locally-available materials. Exotic artifacts are not present in any of the burials. The excavated midden is an excellent snapshot of Caddo domestic life along the Glover, but the center of communal religious life along the Glover clearly was elsewhere. In addition to the larger mound centers of Clement and A.W. Davis, located downstream, the Pine Creek mounds are located upstream in the Ouachita Mountains. The site consists of at least two, and possibly three house mounds tested in the early 1970s (Gettys 1975). Like the Woods Mound group along the Mountain Fork, the ceramic assemblage from Pine Creek consists almost entirely of utilitarian wares. Because the mound assemblages at Woods Mound group included very few finewares associated elsewhere with elite status, Dowd (2012) interprets the Woods Mound group as a community gathering place where the dismantling and burying of structures served to reinforce group solidarity rather than social hierarchy. Based on the published ceramic descriptions (Gettys 1975:153-167), this appears to be the case at the Pine Creek mounds as well. In contrast, the presence of the shaft tomb and platform mound and the number of finewares in the collection from Clement and A. W. Davis suggests the emergence of some degree of social and religious differentiation among the Caddo living along the lower Glover.

The burials in the Mc11 cemetery and those at Mc12 do not reflect any sort of emerging social status. Individuals were buried with anywhere from 1-6 vessels and no other grave goods indicative of elevated social status are reported. Stylistically, the early McCurtain phase vessels and sherds in the McDonald burial assemblage have more in common with pots recovered from the Clement site than the noded and incised sherds illustrated for the Pine Creek mounds. One major difference is that engraved and red-slipped finewares are more common in the Clement burials, while utilitarian jars are the modal form for McDonald burials. The later vessels in the McDonald burial assemblage show clear stylistic ties to the whole vessel assemblage at A.W. Davis, illustrated by Dowd (2008) and Wilson (1962).

While the potters at McDonald made many of the same types of ceramics, down to vessel forms and decorative motifs, as their contemporaries along the Red River, they favored different ceramic pastes during the early McCurtain phase. The overwhelming majority of ceramic assemblages dating between AD 13001450 at sites along the Red River were shell-tempered. In contrast, the McDonald analysis demonstrates that potters along the lower Glover made the transition to using shell as a tempering agent at a later date. Utilitarian 
sherds with early McCurtain phase traits, such as neck banded, castellated jars with loop or strap handles are always grog-tempered. The McDonald assemblage is only $12 \%$ shell-tempered. This ratio appears to be slightly higher at Clement, but still only reaches a maximum of $40 \%$ in a few contexts. In contrast, the A.W. Davis assemblage, which dates to the mid $-15^{\text {th }}$ century at the earliest, is tempered primarily with crushed shell (Wilson 1962:114). While the low ratio of shell tempering at McDonald may simply be due to the fact that the bulk of the midden dates to the earlier part of the McCurtain phase, it is interesting to note that many of the jar sherds with later decorative traits, including v-shaped appliques, are still tempered with grog. This suggests the potters at McDonald were part of a distinct and enduring community where paste recipes remained stable over a long period, even as new decorative techniques and vessel forms were adopted. Even as the potters at related sites downstream were adopting a new paste recipe, the McDonald potters retained their own enduring style.

This analysis of excavations at McDonald have provided an interesting window in the Caddo occupation along the Glover drainage. Although analysis of ceramics from the WPA excavations and the 2008 excavations at the Clement site is not complete, radiocarbon dates demonstrate Clement was initially occupied and mound construction began during the Sanders phase (Hammerstedt et al. 2010). There is very limited evidence of occupation at McDonald during this period. It is unclear whether this is because the excavations simply missed a Sanders phase occupation located elsewhere on the terrace, or whether the Caddo simply weren't extensively inhabiting areas outlying the Clement site until the McCurtain phase. The adoption of maize occurred elsewhere in the Caddo area after AD 1300 (Perttula 2008c). At the same time along the Red River, Caddo residents moved to occupy more dispersed farmsteads, likely to take advantage of soils the soils best suited for cultivation. While no botanical remains were recovered from the site, the fired clay with maize impressions recovered from the hearth in House 1 at Mc12 demonstrates that the McDonald residents did cultivate maize. Based on the burial and ceramic assemblage, the most intensive occupation at the excavated portion of the McDonald site occurred during the early McCurtain phase (AD 1300-1450). The ceramic assemblage at Clement indicates this mound complex was abandoned around AD 1450, and a new mound and occupation area were established just upstream at the A.W. Davis site. While the Clement assemblage includes a number of exotic artifacts typically associated with elevated social status, such as copper clad ear spools and marine artifacts, no exotic artifacts were recovered from the A.W. Davis site, indicating a potential shift in external contacts, social status, a religious life correlated with the abandonment of Clement. It is unclear how these changes, which correspond chronologically to a period of extended drought, may have affected the resident population at McDonald. There are certainly fewer post AD 1450 burials, and only three burials at McDonald can be dated after AD 1650. Because so little of the McDonald site complex is known, these changes may be due less to a decrease in population along the Glover and instead the result of a movement of the McDonald inhabitants to occupy a new area of the terrace.

There is little archaeological evidence that the shift in the religious precinct downstream does not seem to have caused any conflict or an increase in mortality for the residents of the McDonald site. Despite the smaller number of late burials, there does not appear to have been an abrupt break in the use of the community cemetery in the Mc11 midden. Clearly 29 burials is a small number for a four hundred year span, but the ceramic distribution maps make it clear that the artifact scatter, and likely the cemetery, continue in all directions beyond the edges of the grid. Although occupation at McDonald extended well into the contact area, no European trade goods made their way into the few late burials; nor are they present in burials at A.W. Davis. These goods are scarce at sites along the Red River as well. Since all are located above the historic Great Raft, the Caddo of southeast Oklahoma were spared from direct contact with early European expeditions. Unlike the rest of the Southeast, the Caddo were spared the dramatic cultural disruptions wrought by slaving and epidemic disease in the $17^{\text {th }}$ century (Perttula 2012). 
The picture of the McDonald site that emerges from this analysis is that of a large, relatively stable cluster of households that endured in some form over as many as four centuries. While the residents of the McDonald site likely considered the mounds at Clement and later A.W. Davis as a central place for religious ceremonies, the ceramic assemblage, particularly the hesitancy of McDonald potters to adopt shell as their primary tempering agent, indicates they retained some degree of cultural autonomy. The abandonment of the Clement site and the establishment of a new mound center at A.W. Davis during the fifteenth century does not seem to have created a large scale cultural disruption at McDonald, although settlement at the site likely shifted, perhaps in response to drought conditions. Both of these aspects of the McDonald site support the notion that Caddo mound centers in southeast Oklahoma like Clement and A. W. Davis served more as the center of the religious, rather than the political sphere (Regnier 2012). Clement and then A.W. Davis certainly served an essential function of providing a place for the residents of McDonald to interact with the supernatural realm by participating in communal rituals and likely reinforced social ties with among the scattered occupants of the Glover terraces, but the authority of religious leaders does not appear to have extended into a more centralized political authority. In this sense, the political nature of the mounds and outlying sites occupied by the Caddo of southeast Oklahoma are distinctly different from their counterparts in the Mississippian world.

\section{References Cited}

Baerreis, David A.

1942 Quarterly Report of WPA Excavations in Oklahoma, January 1 - March 31, 1942. Manuscript on file at the Oklahoma Archeological Survey, Norman.

Bell, Robert E. and David A. Baerreis

1951 Survey of Oklahoma Archaeology. Bulletin of the Texas Archaeological andPaleontological Society 22:7-100.

Brown, James A.

1996 The Spiro Ceremonial Center. Memoirs of the University of Michigan Museum of Anthropology, No. 20, Vols. 1 and 2. Ann Arbor.

Bruseth, James E.

1998 The Development of Caddoan Polities along the Middle Red River Valley ofEastern Texas and Oklahoma. In The Native History of the Caddo: TheirPlace in Southeastern Archeology and Ethnohistory, edited by Timothy K. Perttula and James E. Bruseth, pp. 9-43. Studies in Archeology No. 30. Texas Archeological Research Laboratory, University of Texas, Austin.

Dowd, Elsbeth Linn

2008 Identifying Variation: A Stylistic Analysis of Four Caddo Pottery Assemblages from Southeastern Oklahoma. Unpublished Masters thesis. Department of Anthropology, University of Oklahoma, Norman.

2010 New Approaches to Old Collections: Identifying Stylistic Variation Among Caddo Pottery from Southeastern Oklahoma. The Arkansas Archaeologist 49:17-32.

2011 Identifying Variation: A Stylistic Analysis of Four Caddo Pottery Assemblages fromSoutheastern Oklahoma. Memoir No. 15. Oklahoma Anthropological Society, Norman.

2012 Alternative Conceptions of Complexity: Sociopolitical Dynamics of the Mountain Fork Caddo. Unpublished Ph.D. Dissertation, Department of Anthropology, University of Oklahoma, Norman. 


\section{References Cited (cont.)}

Gettys, Marshall

1975 Preliminary Report on Archaeological Excavations at Lukfata Reservoir, Southeastern Oklahoma. General Survey Report No. 14. Oklahoma River Basin Survey Project, University of Oklahoma Office of Research Administration, Norman.

Hammerstedt, Scott W., Amanda L. Regnier, and Patrick C. Livingood

2010 Geophysical and Archaeological Investigations at the Clement Site, A Caddo Mound Complex in Southeastern Oklahoma. Southeastern Archaeology 29:279-291.

Hoffman, Michael P.

1967 Ceramic Pipe Style Chronology along the Red River Drainage in Southwestern Arkansas. The Arkansas Archaeologist 8(1):4-14.

Leith, Luther J.

2011 A Re-conceptualization of the Fourche Maline Culture: The Woodland Period as a Transition in Southeast Oklahoma. Unpublished Ph.D. Dissertation, Department of Anthropology, University of Oklahoma, Norman.

Perino, Gregory

1980 Archaeological Research at the Rowland Clark Site, Red River County, Texas. Unpublished manuscript on file at the Museum of the Red River, Idabel.

1981 Archaeological Investigations at the Roden Site, McCurtain County, Oklahoma. Potsherd Press Publication No. 1. Museum of the Red River, Idabel.

1983 Archaeological Research at the Bob Williams Site (41RR16), Red River County, Texas. Museum of the Red River, Idabel.

1994 Archaeological Research at the Rowland Clark Site (41RR7), Red River County, Texas. Journal of Northeast Texas Archaeology 4:3-42.

Perttula, Timothy K.

2008a Archeological Survey of the Roitsch Farm and Adjoining Lands, 1991 and 1992 Texas Archeological Society Field School, Red River County, Texas. In Collected Papers from Past Texas Archeological Society Field Schools, edited by Timothy K. Perttula, pp.152-172. Special Publication No. 5. Texas Archeological Society, Austin.

2008b The Archeology of the Roitsch Site (41RR16), an Early to Historic Caddo Period Village on the Red River in Northeast Texas. In Collected Papers from Past Texas Archeological Society Field Schools, edited by Timothy K. Perttula, pp. 313-628. Special Publication No. 5. Texas Archeological Society, Austin.

2008c Caddo Agriculture on the Western Frontier of the Eastern Woodlands. Plains Anthropologist 53(205): 79-105.

2012 Watershed Times for the Caddo People of the Far Southeast. Caddo Archeology Journal 22:97-114.

Perttula, Timothy K., Mary Beth Trubitt, and Jeffrey S. Girard

2011 The Use of Shell-Tempered Pottery in the Caddo Area of the Southeastern United States. Southeastern Archaeology 30:242-267. 


\section{References Cited (cont.)}

Perttula, Timothy K., Chester P. Walker, and T. Clay Schultz

2008 A Revolution in Caddo Archaeology: The Remote Sensing and Archaeological View from the Hill Farm Site (41BW169) in Bowie County, Texas. Southeastern Archaeology 27:93-107.

Regnier, Amanda L.

2012 The Relationship between Becoming Caddo and Becoming Mississippian in Southeast Oklahoma. Paper presented at the Annual Meeting of the Southeastern Archaeological Conference, Baton Rouge, Louisiana.

Regnier, Amanda L., Patrick C. Livingood, and Scott W. Hammerstedt

2013 The End of the WPA in Oklahoma: The Clement and McDonald Site, in Shovel Ready: Archaeology and Roosevelt's New Deal for America, edited by Bernard Means. University of Alabama Press, Tuscaloosa and London.

Schambach, Frank R.

1982 An Outline of Fourche Maline Culture in Southwest Arkansas. In Arkansas Archaeology in Review, edited by Neil L. Trubowitz and Marvin D. Jeter, pp. 132-197. Research Series Number 15. Arkansas Archeological Survey, Fayetteville.

Wilson, Rex

1962 A. W. Davis Site, Mc6, of McCurtain County, Oklahoma. Bulletin of the Oklahoma Anthropological Society 10:103-152. 